Provided for non-commercial research and education use. Not for reproduction, distribution or commercial use.

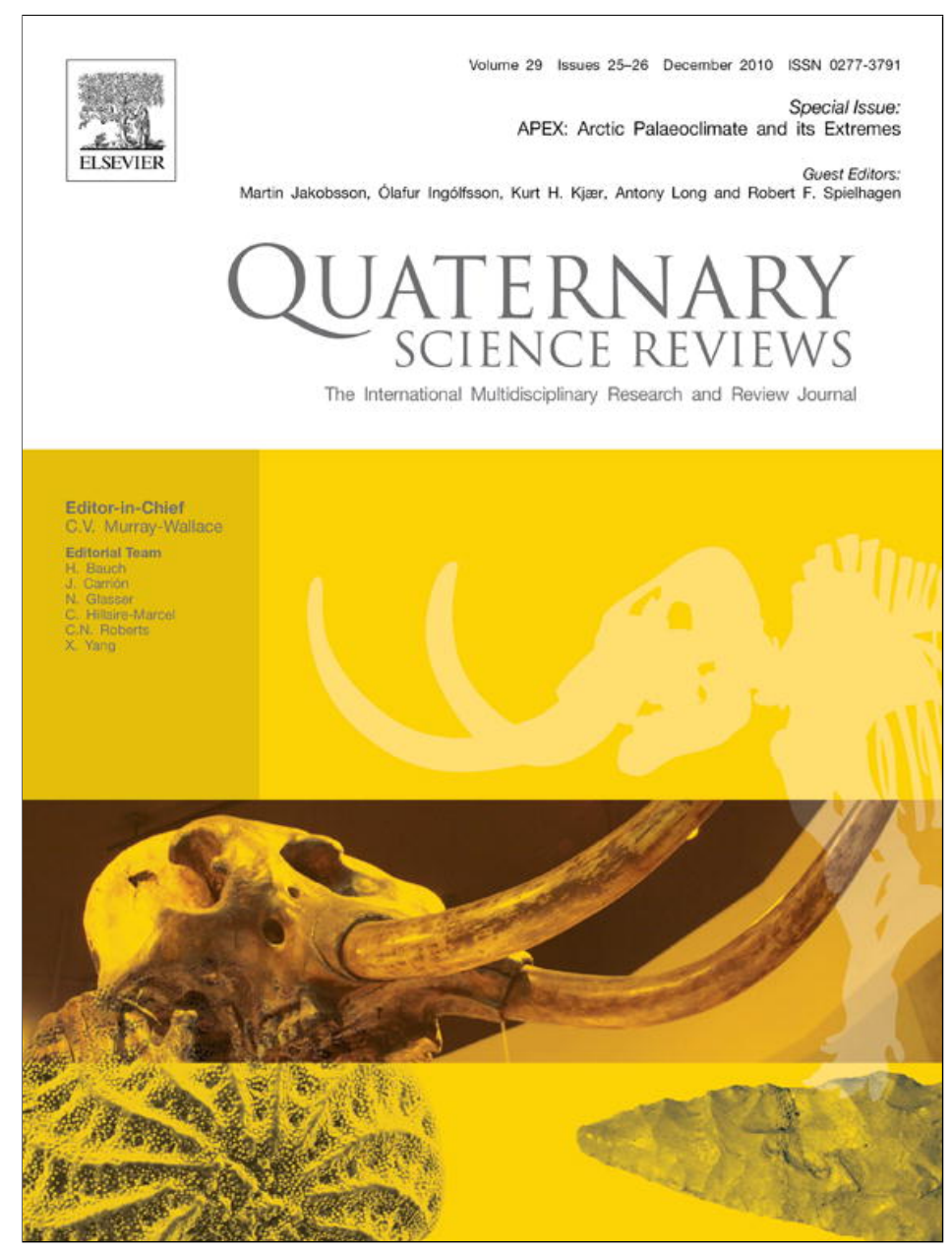

This article appeared in a journal published by Elsevier. The attached copy is furnished to the author for internal non-commercial research and education use, including for instruction at the authors institution and sharing with colleagues.

Other uses, including reproduction and distribution, or selling or licensing copies, or posting to personal, institutional or third party websites are prohibited.

In most cases authors are permitted to post their version of the article (e.g. in Word or Tex form) to their personal website or institutional repository. Authors requiring further information regarding Elsevier's archiving and manuscript policies are encouraged to visit:

http://www.elsevier.com/copyright 


\title{
Spatial and temporal Arctic Ocean depositional regimes: a key to the evolution of ice drift and current patterns
}

\author{
E. Sellén*, M. O’Regan, M. Jakobsson \\ Stockholm University, Department of Geological Sciences, 10691 Stockholm, Sweden
}

\section{A R T I C L E I N F O}

\section{Article history:}

Received 30 November 2009

Received in revised form

1 April 2010

Accepted 3 June 2010

\begin{abstract}
A B S T R A C T
Sediment physical properties measured in cores from all the major ridges and plateaus in the central Arctic Ocean were studied in order to analyze the spatial and temporal consistency of sediment depositional regimes during the Quaternary. In total, six physiographically distinct areas are outlined. In five of these, cores can be correlated over large distances through characteristic patterns in sediment physical properties. These areas are (1) the southern Mendeleev Ridge, (2) the northern Mendeleev Ridge and Alpha Ridge, (3) the Lomonosov Ridge, (4) the Morris Jesup Rise and (5) the Yermak Plateau. Averaged downhole patterns in magnetic susceptibility, bulk density and lithostratigraphy were compiled to establish a composite stratigraphy for each area. In the sixth physiographic area, the Chukchi Borderland, repeated ice-grounding during recent glacial periods complicates the stratigraphy and prevents the compilation of a composite stratigraphy using the studied material. By utilizing published age models for the studied cores we are able to show that the northern Mendeleev Ridge and Alpha Ridge have the lowest average late Quaternary sedimentation rates, while intermediate sedimentation rates prevail on the southern Mendeleev Ridge and the Morris Jesup Rise. The second highest sedimentation rate is observed on the Lomonosov Ridge, whereas the average sedimentation rate on the Yermak Plateau is more than twice as high. The close correlation of physical properties within each area suggests uniform variations in sediment transport through time, at least throughout the later part of the Quaternary. The unique stratigraphic characteristics within each area is the product of similar past depositional regimes and are key for furthering our understanding of the evolution of ice drift and current patterns in the central Arctic Ocean.
\end{abstract}

(c) 2010 Elsevier Ltd. All rights reserved.

\section{Introduction}

The Arctic Ocean is characterized by comparatively large physiographic variations, in spite of being the smallest of the world oceans. The surrounding wide and shallow continental shelves comprise $53 \%$ of the Arctic Ocean's area while the central deep basins are bisected by submarine ridges that account for $16 \%$ of the total area compared to only 3\% for the other world oceans (Menard and Smith, 1966; Jakobsson et al., 2003b). The rivers on the surrounding continents drain huge geologically distinct areas that deliver varying quantities and compositions of suspended sediment to the shelves and basins (Peterson et al., 2002). These facts argue for large spatial heterogeneity in the composition of sediments within the Arctic Ocean and partially explain why a lithostratigraphic framework for the entire basin has not been possible to establish to-date. For example, Clark et al. (1980)

\footnotetext{
* Corresponding author. Tel.: +468 164758 .

E-mail address: emma.sellen@geo.su.se (E. Sellén).
}

presented a general lithostratigraphy valid for the Alpha Ridge, in the Amerasian side of the Arctic Ocean, which is not possible to recognize in cores from the Lomonosov Ridge and the Eurasian side (Sellén et al., 2008).

On the other hand, sediment cores from certain regions can be correlated over large distances (e.g. Clark et al., 1980; Jakobsson et al., 2001; Backman et al., 2004; Spielhagen et al., 2004; O'Regan et al., 2008; Adler et al., 2009), sometimes down to subdecimeter scale changes in the physical properties that reflect subtle variations in sediment composition and grain size (Phillips and Grantz, 2001; O'Regan et al., 2008). Despite the physiographic variability, the modern sea ice cover acts as a homogenizing agent, re-distributing sediments entrained on the margins throughout the basin. This reasoning leads to speculation that sediments deposited under similar surface circulation and subsurface current regimes should display similar compositional and grain size characteristics, which are the main controls on physical property data, namely bulk density, compressional wave velocity and magnetic susceptibility (Hounslow and Maher, 1999; Moran et al., 2007). 
At the $\mathrm{cm} / \mathrm{ka}$ temporal resolution of most central Arctic Ocean cores collected away from the margins, short-term (decadal through millennial) variations in circulation or sea ice are not preserved in the sediments. However, on longer timescales encompassing glacial/interglacial cycles, changes in sediment entrainment and distribution should be distinguished. In the last 10-15 years there has been a dramatic increase in the number of cores collected from icebreaker expeditions in the Arctic Ocean. Together with advances in rapid non-destructive, high-resolution measurement techniques (principally of physical properties) we are now able to better characterize and compare lithostratigraphic changes in marine sediments and resolve how uniform they are in different regions of the basin.

The ability to recognize and correlate synchronous changes in the physical properties of sediments is especially important in the Arctic due to existing difficulties in dating Arctic Ocean sediments (Backman et al., 2004; Sellén et al., 2009). Age models for Arctic sediments are frequently revised and lack the resolution and certainty attainable in marine sediments from other ocean basins. This poses a particular challenge when two independently dated records are used to interpret spatial and temporal changes in paleoceanographic conditions.
The 2005 Healy-Oden Trans-Arctic Expedition (HOTRAX) recovered piston cores and multi-cores along a pan-Arctic transect extending from the Alaskan to Svalbard margin (Fig. 1) (Darby et al., 2005). Here, we study all piston cores retrieved along the HOTRAX transect together with four cores taken from the Morris Jesup Rise during the Lomonosov Ridge off Greenland (LOMROG) 2007 expedition (Jakobsson et al., 2008b). The objective is to characterize the spatial and temporal variability in depositional patterns using physical property data and through establishing regional stratigraphic frameworks to address the paleoceanographic mechanisms behind different Quaternary sedimentation regimes.

\section{Geologic and oceanographic overview}

\subsection{Physiography}

Most coring efforts have focused on the recovery of material from prominent bathymetric ridges that bisect, or protrude into, the deeper basins of the Arctic Ocean; primarily the Alpha and Mendeleev ridges, Chukchi Borderland, Lomonosov Ridge, Morris Jesup Rise and Yermak Plateau (Fig. 1). The length of these cores, generally $<10 \mathrm{~m}$, and the overall low sedimentation rates that are

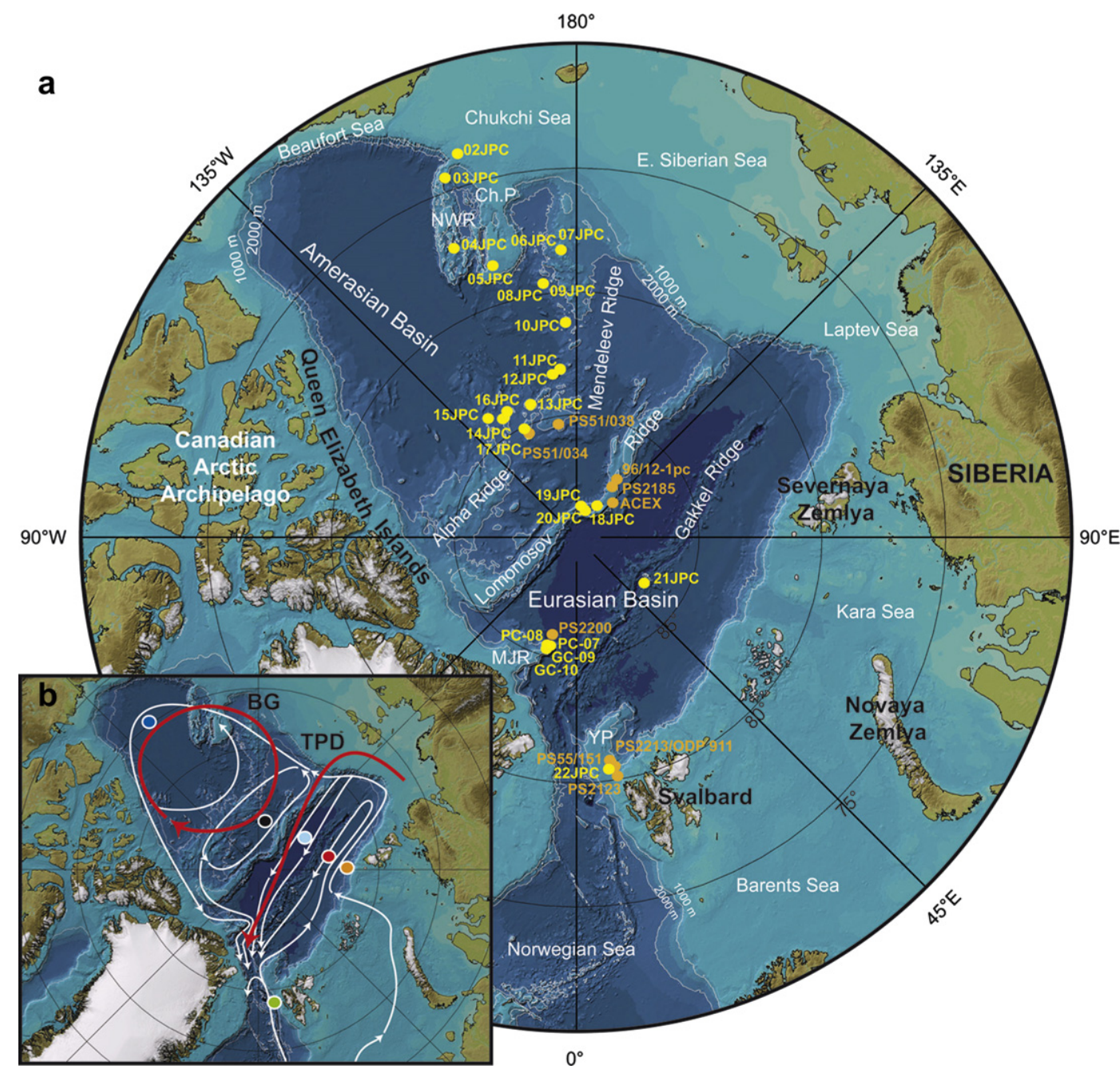

Fig. 1. a) Schematic map of the Arctic Ocean (IBCAO 2.0, Jakobsson et al., 2008a) with core sites (yellow dots) from the HOTRAX 2005 expedition and the LOMROG expedition (Darby et al., 2005; Jakobsson et al., 2008b) and cores from earlier expeditions (orange dots) included in this study (see Table 1). Abbreviations used: Ch.P - Chukchi Plateau; NWR Northwind Ridge; MJR - Morris Jesup Rise; YP - Yermak Plateau. b) The intermediate water circulation (white arrows) and the dominant surface currents (red arrows): the Beaufort Gyre (BG) and the Transpolar Drift (TPD). The dots represent stations where temperature and salinity profiles (see Fig. 2) were recovered in the different basins (Rudels et al., in press). 
characteristic for much of the basin $(\mathrm{cm} / \mathrm{ka})$ indicate that the recovered sediment only sample the more recent part of the Quaternary. In order to place the sampled stratigraphies in the context of the Arctic Ocean geologic evolution, an overview of the physiography of the submarine ridge systems is required.

The Amerasian Basin of the Arctic Ocean is divided into the Canada Basin and the Makarov Basin by the Alpha and Mendeleev ridges (Fig. 1). This ridge complex stretches more than $1800 \mathrm{~km}$, from the Canadian continental margin off Ellesmere Island to the Eastern Siberian Sea shelf and includes several sea mounts and valleys with depths ranging from 740 to $2000 \mathrm{~m}$ water depth (Jakobsson et al., 2003b). Recovered basaltic rocks indicate a Late Cretaceous age for the formation of the Alpha Ridge (Jokat, 2003) and the sediments that drape the ridge crest range in thickness from $500 \mathrm{~m}$ to about $1500 \mathrm{~m}$ (Jokat, 2003; Lebedeva-Ivanova et al., 2006), although local areas subjected to erosion are characterized by significantly thinner drapes (Jenkyns et al., 2004).

The Chukchi Borderland, which includes the Northwind Ridge and the Chukchi Plateau, is situated within the Canada Basin and extends roughly $600 \mathrm{~km}$ out from the Chukchi continental shelf (Fig. 1). These bathymetric highs have steep slopes and relatively flat crests found at generally less than $1000 \mathrm{~m}$ water depths $(600 \mathrm{~m}$ for the Chukchi Plateau) (Hall, 1990; Jakobsson et al., 2003b). Recent geophysical mapping has revealed extensive glacial erosion down to $900 \mathrm{~m}$ water depth (Polyak et al., 2001; Darby et al., 2005; Jakobsson et al., 2005; Polyak et al., 2007; Jakobsson et al., 2008c). This information is critical when interpreting the stratigraphy in cores from this area.

The Amerasian Basin is separated from the Eurasian Basin by the Lomonosov Ridge, which extends more than $1500 \mathrm{~km}$ from the Siberian continental margin to the northern Greenland margin (Fig. 1). Its shallowest part is located north of Canada and Greenland with water depths less than $1000 \mathrm{~m}$. The sediment thickness atop the ridge ranges from a few tens of meters to well over $1000 \mathrm{~m}$ (Jackson and Oakey, 1990; Jokat, 2005; Kristoffersen and Mikkelsen, 2006). The Lomonosov Ridge was the target for the Integrated Ocean Drilling Program (IODP) Expedition 302 (the Arctic Coring Expedition; ACEX). Approximately $428 \mathrm{~m}$ of sediment draping the ridge, encompassing the past $56 \mathrm{Ma}$, were cored near $88^{\circ} \mathrm{N}$ during ACEX (Moran et al., 2006). The recovered Neogene sediment is characterized by oxygenated silty mud with numerous thin sand lenses and dropstones and indicates a generally persistent mode of glaciomarine deposition since about 17.5 Ma (Backman et al., 2008). At the center of the ridge there is a depression, the Intra Basin, with a sill depth of $1870 \mathrm{~m}$ towards the Makarov Basin and $2400 \mathrm{~m}$ towards the Amundsen Basin (Björk et al., 2007). Results from a detailed ${ }^{14} \mathrm{C}$ study on a core within this basin show a relatively high sedimentation rate of $7-9 \mathrm{~cm} / \mathrm{ka}$ during the last deglaciation, possibly indicating that the Intra Basin is a local sediment trap (Hanslik et al., this issue). Similar to the Chukchi Borderland, the shallow portions of the Lomonosov Ridge $(<1000 \mathrm{~m})$ were subjected to ice-grounding, with the oldest dated event being associated with marine isotope stage (MIS) 6 (Jakobsson et al., 2001; Polyak et al., 2001; Jakobsson et al., 2008c).

The Morris Jesup Rise extends northwards from the northern Greenland shelf into the Amundsen Basin and has an area of approximately $5000 \mathrm{~km}^{2}$ (Fig. 1). The water depths of the rise range from 500 to $2500 \mathrm{~m}$. Recent sub-bottom profiles and multibeam studies revealed extensive iceberg scouring down to a water depth of about $1050 \mathrm{~m}$ on the rise (Spielhagen et al., 2004; Jakobsson et al., this issue). On the other side of the Gakkel ridge lies the Yermak Plateau (Fig. 1), a conjugate feature to Morris Jesup Rise, both formed around $34 \mathrm{Ma}$ (Brozena et al., 2003). The Yermak Plateau extends $400 \mathrm{~km}$ into the Nansen Basin from the Svalbard Margin with depths from 500 to $1000 \mathrm{~m}$. Whereas the eastern part of the plateau is blocky and rough, the southwestern and northern parts have a smoother topography (Myhre and Thiede, 1995). Thick sediment drapes the plateau and results from the Ocean Drilling Program (ODP) Leg 151 indicate relatively high sedimentation rates for the Plio-Pleistocene (on average $14 \mathrm{~cm} / \mathrm{ka}$ ) (Knies et al., 2009). Ice has eroded large parts of the plateau at water depths ranging from 450 to $850 \mathrm{~m}$ (Dowdeswell et al., this issue; Vogt et al., 1994; Kristoffersen et al., 2004).

\subsection{Arctic Ocean circulation}

The modern Arctic Ocean surface circulation (Fig. 1) is dominated by the Beaufort Gyre in the Amerasian Basin and the Transpolar Drift flowing from the Siberian shelves along the Lomonosov Ridge towards the Fram Strait (Aagaard et al., 1985; Rudels et al., in press). These surface currents define the major transport paths for modern sea ice and icebergs, which ultimately distribute sediment from the continental shelves throughout the Arctic Ocean (Pfirman et al., 1997).

Today, there is an exchange of water between the Arctic, Pacific and Atlantic Oceans through the Bering Strait, the Canadian Arctic Archipelago and the Fram Strait/Barents Sea. Low salinity Pacific waters enter the Arctic Ocean through the relatively narrow and shallow Bering Sea (with a sill depth of $50 \mathrm{~m}$ ) and contribute to the Polar Surface Water (Woodgate and Aagaard, 2005; Rudels et al., in press). In addition, the Polar Surface Water receives freshwater from the rivers draining Siberia and North America (Woodgate and Aagaard, 2005). This cold, low salinity layer is separated from warmer water masses by a cold halocline layer (Fig. 2) (Rudels et al., in press).

The Arctic Ocean intermediate waters can be divided into the Atlantic layer (250-600 m) and the Upper Polar Deep Water (600-1700 m) (Fig. 2). Relatively warm and saline water from the Atlantic Ocean enters the Arctic across the Barents Sea and through the Fram Strait (Fig. 1). The Upper Polar Deep Water is a mixture of Atlantic water and cold saline shelf water that sinks to this level and cools the surrounding water mass (Rudels, 1995; Rudels et al., in press). The intermediate waters circulate anti-clockwise in the Eurasian Basin and flow into the Makarov Basin, between the Lomonosov Ridge and the Siberian shelf (Fig. 1). The flow continues along two paths: one follows the edges of the Canada Basin and the other along the northern slopes of the Alpha Ridge. Portions of this water mass eventually re-circulate to the Eurasian Arctic through an Intra Basin in the Lomonosov Ridge and across the southernmost connection to the northern Greenland shelf (Björk et al., 2007; Rudels et al., in press). The Arctic Ocean Deep and Bottom Waters are mainly formed by brine rejection and also flow anti-clockwise through the basins (Rudels et al., in press).

The Amerasian Basin water masses join the Eurasian Basin waters through the gap between the Lomonosov Ridge and Greenland before exiting through the narrow Fram Strait (Björk et al., 2007). Due to the depths of the ridges bordering the Arctic Ocean basins, sediment cores collected during the HOTRAX and LOMROG expedition, and additional cores incorporated in this study, sample sediments deposited within the Upper Polar Deep Water or the deep waters (Fig. 2).

\subsection{Sediment transportation}

Away from the continental shelves, sea ice and icebergs are the dominant mechanism for transporting terrigenous sediments, and are driven by modern surface circulation patterns. As the principal "exit gateway" of ice the Fram Strait receives a mixture from both Amerasian and Eurasian sources. The main area for sea ice production is the Siberian shelves, especially the Laptev Sea, 

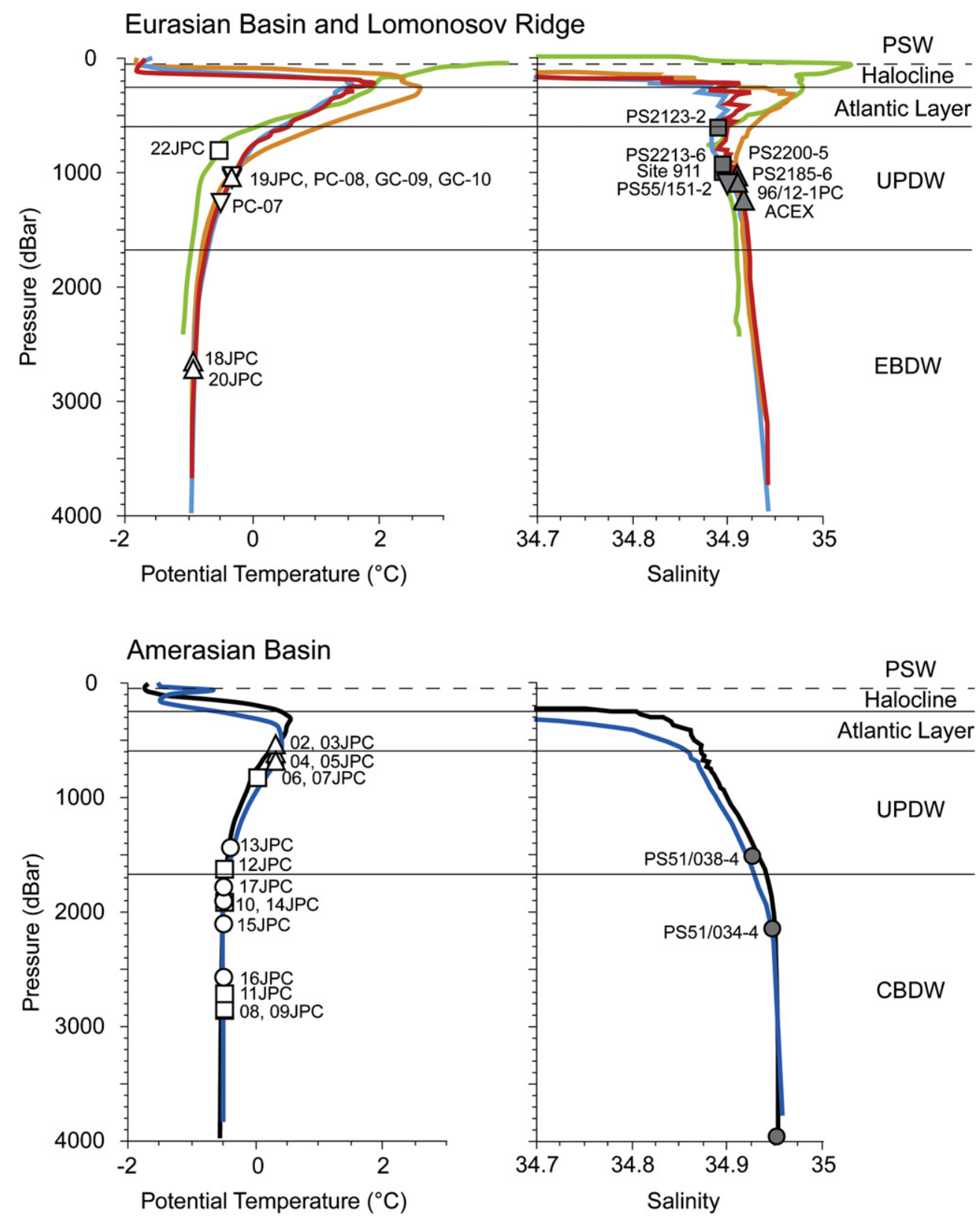

Fig. 2. All included core sites in relation to the water masses (adapted from Rudels et al., in press), potential temperature and salinity (PSW - Polar Surface Water; UPDW - Upper Polar Deep Water; EBDW - Eurasian Basin Deep Water; CBDW - Canadian Basin Deep Water). The water samples are taken in the Western Svalbard Current (green), the Nansen Basin within the Fram Strait branch (orange), the interior Nansen Basin (red), the Amundsen Basin (light blue), the Makarov Basin (black) and the Canada Basin (blue). The positions of the stations are marked on the map in Fig. 1.

although sea ice is naturally produced along all of the Arctic Ocean continental shelves.

During interglacial periods sea ice is the main carrier of clastic sediment but occasional discharge of icebergs from the surrounding glaciers occurs as well (Bischof, 2000). However, the surface circulation was likely different during glacial times when eustatic levels are estimated to have dropped between 86 and $102 \mathrm{~m}$ below present level during MIS 2, 6 and 8 and up to $150 \mathrm{~m}$ during MIS 10 and 12 (Rabineau et al., 2007). This sea level change would expose much of the continental shelf areas and close the 40-50 m deep Bering Strait.

Provenance studies of ice rafted debris (IRD) indicate that the Beaufort Gyre was different during late Pleistocene glacial periods. Sediment incorporated into sea ice and icebergs in the southwestern Canadian Arctic Archipelago was transported more directly towards the Northwind Ridge and the Chukchi Plateau and sediment entrained in the Queen Elizabeth Islands towards the central and southeastern Alpha Ridge and Fram Strait (Bischof and Darby, 1997). This enabled icebergs originating from the Laurentide Ice Sheet and the Innuitian Ice Sheet to exit the Arctic Ocean rapidly. Furthermore, the provenance studies of Bischof and Darby (1997) indicate that sea ice during the late Pleistocene continued to drift from the Siberian Shelf region along a similar pattern as the modern Transpolar drift. The inflow of Atlantic water was reduced during glacials, causing the deep-water ventilation that occurs in the North Atlantic today to move further south and the Upper Polar Deep Waters (intermediate water) that today extend to depths of $1700 \mathrm{~m}$, being replaced by waters originating from brine rejection during sea ice formation, mainly in the Kara Sea (Haley et al., 2008). 
Provenance studies based on clay and heavy mineral assemblages in sediment cores from the central Lomonosov Ridge and the Morris Jesup Rise point to the Kara, Laptev, and Barents Sea as the major source areas for terrigenous material during the last two glacial cycles (Spielhagen et al., 2004). In sediment cores from the Amerasian Basin, IRD assemblages and individual Fe oxide mineral grains indicate that the main source of IRD is the Canadian Arctic Archipelago and the Banks Island shelf (Darby, 1989, 2003). Lower resolution studies also revealed that terrigenous sediment from both the Siberian and Canadian Arctic shelves coexist within the Neogene-Quaternary section of the ACEX record (Darby, 2008; Krylov et al., 2008; Vogt, 2009).

\section{Methods}

During the HOTRAX expedition 21 piston cores (Table 1), on average $10 \mathrm{~m}$ long and $11.4 \mathrm{~cm}$ outer diameter, were retrieved along a transect from the Chukchi Borderland, across the Arctic Ocean, to the Yermak Plateau (Fig. 1) (Darby et al., 2005). In addition, four piston cores that were collected from the Morris Jesup Rise during the LOMROG 2007 expedition are included in this study (Table 1 ). All sediment cores were digitally photographed and visually described when split.

Prior to splitting, bulk density and magnetic susceptibility were measured shipboard with Stockholm University's Multi-Sensor Core Logger (MSCL, Geotek Ltd., UK). The cores were logged in plastic liners following the procedure described in the Geotek MSCL manual (Geotek, 2004). The principles of logging cores on the MSCL are outlined in Weber et al. (1997) and Best and Gunn (1999). Magnetic susceptibility was measured using a Bartington loop sensor with a diameter of $12.5 \mathrm{~cm}$ for the HOTRAX cores and $10 \mathrm{~cm}$ for the LOMROG cores. There was no correction applied for the loop diameter so comparisons between the absolute magnetic susceptibility values are not made in this study. The MSCL estimates bulk density from the attenuation of a gamma-ray beam transmitted by a radioactive source $\left({ }^{137} \mathrm{Cs}\right)$. These measurements were made with a $5 \mathrm{~mm}$ collimator and using a $15 \mathrm{~s}$ count time. Calibration of the estimated densities is performed by measuring the attenuation of gamma rays in standards made of variable thicknesses of aluminum and water (Geotek, 2004). Some of the magnetic susceptibility and bulk density records from different studies display varying magnitudes caused by differences in equipment. In order to stack these records the data was plotted on a standardized scale.

Bulk density is a measurement influenced by grain size, composition and porosity (Weber et al., 1997; Niessen et al., 2007). The reduction in porosity due to downhole compaction, or past stress history, is the over-riding influence on the absolute bulk density measurement. However, relative variations in bulk density that occur on centimeter to decimeter scales are mostly linked to changes in sediment composition and clay fraction Hounslow and Maher, 1999; Moran et al., 2007.

The magnetic susceptibility reflects variation in the concentration and composition of magnetic material in the sample (Verosub

Table 1

All cores included in the study, references used are a) Darby et al., 2005; b) Adler et al., 2009; c) Jakobsson et al., 2008b; d) Stein et al., 2004; e) Spielhagen et al., 2004; f) Jokat, 1999a g) Fütterer, 1992; h) Jakobsson et al., 2001; i) O’Regan et al., 2008; j) Bergmann, 1996; k) Spielhagen et al., 2004; l) Nowaczyk and Frederichs, 2009; m) Aldahan et al. 1997; n) Knies, 1994; o) Jokat, 2000; p) Rack et al., 1996.

\begin{tabular}{|c|c|c|c|c|}
\hline Core Name & Position (lat ${ }^{\circ} \mathrm{N}$; long $\left.{ }^{\circ} \mathrm{E}\right)$ & Depth (m) & Location & Included measurements \\
\hline HLY0503-02JPC ${ }^{a}$ & $74.4925 ;-159.8898$ & 627 & Northwind Ridge & Magnetic susceptibility, bulk density \\
\hline HLY0503-03JPC ${ }^{a}$ & $77.2450 ;-157.0600$ & 594 & Northwind Ridge & Magnetic susceptibility, bulk density \\
\hline HLY0503-04JPC ${ }^{a}$ & $77.2187 ;-157.0485$ & 520 & Northwind Ridge & Magnetic susceptibility, bulk density \\
\hline HLY0503-05JPC ${ }^{a}$ & $78.4406 ;-162.6624$ & 660 & Chukchi Plateau & Magnetic susceptibility, bulk density \\
\hline HLY0503-06JPC ${ }^{a}$ & $78.2938 ;-176.986$ & 802 & Mendeleev Ridge & Magnetic susceptibility, bulk density, lithology \\
\hline HLY0503-07JPC ${ }^{a}$ & $78.2987 ;-176.0877$ & 802 & Mendeleev Ridge & Magnetic susceptibility, bulk density, lithology \\
\hline HLY0503-08JPC ${ }^{\mathrm{a}, \mathrm{b}}$ & $79.5928 ;-172.5016$ & 2792 & Mendeleev Ridge & $\begin{array}{l}\text { Magnetic susceptibility, bulk density, lithology, coarse fraction, } \\
\text { foraminifers, inclination, age model }\end{array}$ \\
\hline HLY0503-09JPC ${ }^{a}$ & $79.5934 ;-172.4611$ & 2783 & Mendeleev Ridge & Magnetic susceptibility, bulk density, lithology \\
\hline HLY0503-10JPC ${ }^{a}$ & $81.2261 ;-177.1935$ & 1865 & Mendeleev Ridge & Magnetic susceptibility, bulk density, lithology \\
\hline HLY0503-11JPC ${ }^{a}$ & $83.1436 ;-174.5372$ & 2644 & Mendeleev Ridge & Magnetic susceptibility, bulk density, lithology \\
\hline HLY0503-12JPC ${ }^{a}$ & $83.2911 ;-171.9577$ & 1585 & Mendeleev Ridge & Magnetic susceptibility, bulk density, lithology \\
\hline HLY0503-13JPC ${ }^{a}$ & $84.3056 ;-160.6792$ & 1400 & Alpha Ridge & Magnetic susceptibility, bulk density, lithology \\
\hline HLY0503-14JPC ${ }^{\mathrm{a}}$ & $84.3033 ;-149.0340$ & 1856 & Alpha Ridge & Magnetic susceptibility, bulk density, lithology \\
\hline HLY0503-15JPC ${ }^{a}$ & $83.9502 ;-143.1828$ & 2047 & Alpha Ridge & Magnetic susceptibility, bulk density, lithology \\
\hline HLY0503-16 JPC ${ }^{a}$ & $84.1690 ;-150.9582$ & 2506 & Alpha Ridge & Magnetic susceptibility, bulk density, lithology \\
\hline HLY0503-17JPC ${ }^{a}$ & $85.1272 ;-154.7784$ & 1741 & Alpha Ridge & Magnetic susceptibility, bulk density, lithology \\
\hline HLY0503-18JPC ${ }^{a}$ & $88.4505 ; 146.5609$ & 2598 & Lomonosov Ridge & Magnetic susceptibility, bulk density, lithology \\
\hline HLY0503-19JPC ${ }^{a}$ & $88.7151 ; 169.7857$ & 1023 & Lomonosov Ridge & Magnetic susceptibility, bulk density \\
\hline HLY0503-20JPC ${ }^{a}$ & $88.8060 ; 163.5796$ & 2654 & Lomonosov Ridge & Magnetic susceptibility, bulk density \\
\hline HLY0503-21JPC ${ }^{a}$ & $86.6623 ; 55.7166$ & 2333 & Gakkel Ridge & Magnetic susceptibility, bulk density \\
\hline HLY0503-22JPC ${ }^{a}$ & $80.4898 ; 7.7690$ & 798 & Yermak Plateau & Magnetic susceptibility, bulk density \\
\hline LOMROG07-PC-07c & $85.3997 ;-14.282$ & 1252 & Morris Jesup Rise & Magnetic susceptibility, bulk density, lithology \\
\hline LOMROG07-PC-08 ${ }^{\mathrm{C}}$ & $85.3198 ;-14.8575$ & 1038 & Morris Jesup Rise & Magnetic susceptibility, bulk density, lithology \\
\hline LOMROG07-GC-09c & $85.2945 ;-14.8922$ & 1016 & Morris Jesup Rise & Magnetic susceptibility, bulk density, lithology \\
\hline LOMROG07-GC-10 & $85.2931 ;-14.8146$ & 1017 & Morris Jesup Rise & Magnetic susceptibility, bulk density, lithology \\
\hline PS51/034- $4^{\mathrm{d}}$ & $85.3767 ;-155.4617$ & 2071 & Alpha Ridge & Magnetic susceptibility, bulk density, \\
\hline PS51/038-4 ${ }^{\mathrm{e}, \mathrm{f}}$ & $85.1350 ;-171.4417$ & 1473 & Alpha Ridge & $\begin{array}{l}\text { Magnetic susceptibility, bulk density, coarse fraction, age model, } \\
\text { foraminifers, inclination }\end{array}$ \\
\hline PS2185-6 $6^{\mathrm{g}}$ & $87.5367 ; 144.9267$ & 1051 & Lomonosov Ridge & Magnetic susceptibility, bulk density, lithology \\
\hline $96 / 12-1 p c^{h}$ & $87.1308 ; 144.4395$ & 1003 & Lomonosov Ridge & $\begin{array}{l}\text { Magnetic susceptibility, bulk density, lithology, coarse fraction, } \\
\text { foraminifers, inclination, age model }\end{array}$ \\
\hline ACEX $^{\mathrm{i}}$ & $87.9212 ; 139.0318$ & 1209 & Lomonosov Ridge & Magnetic susceptibility, bulk density, lithology \\
\hline PS2200-5 $5^{\mathrm{j}, \mathrm{k}, \mathrm{l}}$ & $85.3267 ; 14.0000$ & 1074 & Morris Jesup Rise & $\begin{array}{l}\text { Magnetic susceptibility, bulk density, lithology, coarse fraction, } \\
\text { foraminifers, inclination, age model }\end{array}$ \\
\hline PS2213-3/6 & $80.4713 ; 8.2052$ & 897 & Yermak Plateau & Magnetic susceptibility, bulk density, lithology, ${ }^{10} \mathrm{be}$, inclination \\
\hline PS2123- $2^{\text {n }}$ & $80.1555 ; 9.8478$ & 573 & Yermak Plateau & Magnetic susceptibility, bulk density \\
\hline PS55/151-2 ${ }^{\circ}$ & $80.7245 ; 8.0220$ & 971 & Yermak Plateau & Magnetic susceptibility, bulk density \\
\hline ODP $151-911^{\mathrm{p}}$ & $80.4774 ; 8.2273$ & 902 & Yermak Plateau & Magnetic susceptibility, bulk density, lithology \\
\hline
\end{tabular}


and Roberts, 1995) and arise from changes in detrital and authigenic magnetic mineral composition as well as the abundance of diamagnetic biogenic material that will dilute the concentration of magnetic minerals (Hounslow and Maher, 1999).

The MSCL measured physical property records were used to stratigraphically align cores from individual physiographic areas (see Table 2). This was accomplished using the Correlator software developed by the Lamont-Doherty Earth Observatory for the Ocean Drilling Program (http://sqlcore.geo.umn.edu/CoreWallDatabase/ cwWiki/index.php/Correlator). The correlations presented are the best estimate of the stratigraphic alignments, however, alternate interpretations may exist. Towards the bottom of the cores, the correlations are less well constrained due to that core disturbances, such as stretching, generally increases downcore. The successfully correlated physical property records were aligned and projected onto a common depth scale, dictated by one of the cores within each physiographic region.

The average depths of the regional tie points (Table 2) were then used to produce an average composite depth scale, referred to as meter composite depth (mcd) from now on. The composite record for each region was produced by averaging the stratigraphically aligned cores following re-sampling (at $1 \mathrm{~cm}$ ) and smoothing $(5 \mathrm{~cm}$ running mean). The resulting stacked record should, to some extent, reduce the effect of small errors in the stratigraphic alignment between cores. The variability of the composite data (expressed as one standard deviation) was also calculated and used to represent the accuracy of the stratigraphic alignment.

\section{Results}

\subsection{Stratigraphic correlation}

The results showing stratigraphic alignment of cores using magnetic susceptibility and bulk density are initially presented separately for six different geographical areas (1) the Chukchi Borderland (2) southern Mendeleev Ridge (3) northern Mendeleev Ridge and the Alpha Ridge (4) the Lomonosov Ridge (5) the Morris Jesup Rise and (6) the Yermak Plateau. This was done to first assess

Table 2

Depths $(\mathrm{m})$ of the regional tie points in all cores used in the composite stratigraphies. An asterisk marks the cores for which the measurements were averaged to form the composite physical property records. The scale factor indicates the approximate average number the core lengths need to be multiplied with to equal the length of the composite record for each area.

\begin{tabular}{|c|c|c|c|c|c|c|c|c|c|c|c|c|}
\hline \multicolumn{13}{|c|}{ Southern Mendeleev Ridge } \\
\hline Core & MR1 & & MR2 & MR3 & & MR4 & MR5 & MR6 & MR7 & MR8 & MR9 & Scale factor \\
\hline 06JPC* & - & & 0.88 & 1.77 & & 3.02 & 5.07 & 5.65 & 6.35 & 8.58 & 9.05 & 1.10 \\
\hline 07JPC* & - & & 2.59 & 3.93 & & 5.17 & 6.82 & 7.23 & 7.95 & 10.10 & 10.60 & 0.94 \\
\hline 08JPC* & 0.43 & & 4.25 & 5.58 & & 6.61 & 7.84 & 8.12 & 8.50 & 9.97 & 10.27 & 0.96 \\
\hline 09JPC* & 0.40 & & 3.30 & 4.85 & & 5.95 & 7.16 & 7.37 & 7.75 & 9.33 & 9.75 & 1.02 \\
\hline Av. depth: & 0.42 & & 2.76 & 4.03 & & 5.19 & 6.72 & 7.09 & 7.64 & 9.50 & 9.92 & \\
\hline \multicolumn{13}{|c|}{ Northern Mendeleev Ridge and Alpha Ridge } \\
\hline$\overline{\text { Core }}$ & & AR1 & & AR2 & & AR3 & & AR4 & AR5 & & AR6 & $\overline{\text { Scale factor }}$ \\
\hline 10JPC & & 0.34 & & 1.36 & & 4.05 & & 5.02 & 5.66 & & - & 1.20 \\
\hline $11 \mathrm{JPC}$ & & 0.38 & & 1.45 & & 5.50 & & 6.98 & 7.42 & & - & 0.92 \\
\hline $12 J P^{*}$ & & 0.57 & & 1.39 & & 5.38 & & 7.14 & 8.40 & & - & 0.81 \\
\hline $13 \mathrm{JPC}^{*}$ & & 0.51 & & 1.78 & & 5.72 & & 7.75 & 8.76 & & - & 0.78 \\
\hline $14 J P^{*}$ & & 0.32 & & 1.18 & & 4.33 & & 5.30 & 5.96 & & 9.64 & 1.00 \\
\hline 15JPC* & & 0.19 & & 0.93 & & 2.94 & & 3.87 & 4.50 & & 8.17 & 1.18 \\
\hline $16 \mathrm{JPC}$ & & 0.42 & & 1.56 & & 4.72 & & 5.63 & 6.24 & & 9.38 & 1.03 \\
\hline $17 J P C^{*}$ & & 0.38 & & 1.41 & & 4.83 & & 6.46 & 7.53 & & 11.50 & 0.84 \\
\hline PS51/034-4 & & 0.49 & & 1.85 & & 5.92 & & - & - & & - & 0.83 \\
\hline PS51/038-4 & & 0.64 & & 2.67 & & 5.70 & & - & - & & - & 0.86 \\
\hline Av. depth & & 0.42 & & 1.56 & & 4.91 & & 6.02 & 6.81 & & 9.67 & \\
\hline \multicolumn{13}{|c|}{ Lomonosov Ridge } \\
\hline Core & LR1 & & LR2 & & LR3 & LR4 & & LR5 & LR6 & LR7 & LR8 & Scale factor \\
\hline ACEX* & 0.40 & & 1.56 & & 4.64 & 5.58 & & 7.18 & 8.71 & 10.65 & 12.27 & 0.81 \\
\hline $18 \mathrm{JPC}^{*}$ & 0.75 & & 2.08 & & 4.42 & 5.22 & & 6.54 & 7.44 & 9.34 & 10.41 & 0.96 \\
\hline PS2185-6* & 0.20 & & 1.25 & & 3.10 & 3.65 & & 4.90 & 6.10 & & & 1.09 \\
\hline $96 / 12-1 \mathrm{pc}^{*}$ & 0.35 & & 1.64 & & 2.57 & 2.84 & & 3.51 & 4.37 & 5.76 & 7.20 & 1.38 \\
\hline Av. depth & 0.43 & & 1.63 & & 3.68 & 4.32 & & 5.53 & 6.66 & 8.58 & 9.96 & \\
\hline \multicolumn{13}{|c|}{ Morris Jesup Rise } \\
\hline$\overline{\text { Core }}$ & MJR1 & & MJR2 & & MJR3 & MJR4 & & MJR5 & MJR6 & MJR7 & MJR8 & $\overline{\text { Scale factor }}$ \\
\hline PC-07* & 0.85 & & 1.17 & & - & - & & 2.23 & 2.50 & - & - & 1.04 \\
\hline PC- $08^{*}$ & 0.55 & & 0.83 & & 1.09 & 1.57 & & 2.20 & 2.44 & 2.63 & 4.07 & 1.03 \\
\hline GC-09* & 0.50 & & 0.68 & & 0.87 & - & & - & - & - & - & 1.13 \\
\hline GC- $10^{*}$ & - & & - & & 0.59 & 0.95 & & - & - & - & - & 1.54 \\
\hline PS2200-5* & 0.60 & & 0.95 & & 1.36 & 1.85 & & 2.59 & 2.86 & 3.13 & 4.36 & 0.97 \\
\hline Av. depth & 0.62 & & 0.91 & & 0.98 & 1.46 & & 2.34 & 2.60 & 2.88 & 4.21 & \\
\hline \multicolumn{13}{|c|}{ Yermak Plateau } \\
\hline Core & & YP1 & & YP2 & & YP3 & & YP4 & YP5 & & YP6 & Scale factor \\
\hline 22JPC* & & 0.73 & & 1.66 & & 4.27 & & 7 & 9.46 & & 11.19 & 1.38 \\
\hline $151-911^{*}$ & & 1.02 & & 2.45 & & 6.65 & & 12.07 & 18.48 & & 22.51 & 0.69 \\
\hline PS2213-3/6* & & 0.38 & & 1.26 & & 3.98 & & 7.38 & 10.33 & & 12.68 & 1.22 \\
\hline PS2123-2* & & 1.18 & & 2.63 & & 5.65 & & - & - & & - & 0.91 \\
\hline PS55/151-2* & & 0.85 & & 2.28 & & 5.04 & & - & - & & - & 1.02 \\
\hline Av. depth & & 0.83 & & 2.06 & & 5.12 & & 8.82 & 12.76 & & 15.46 & \\
\hline
\end{tabular}



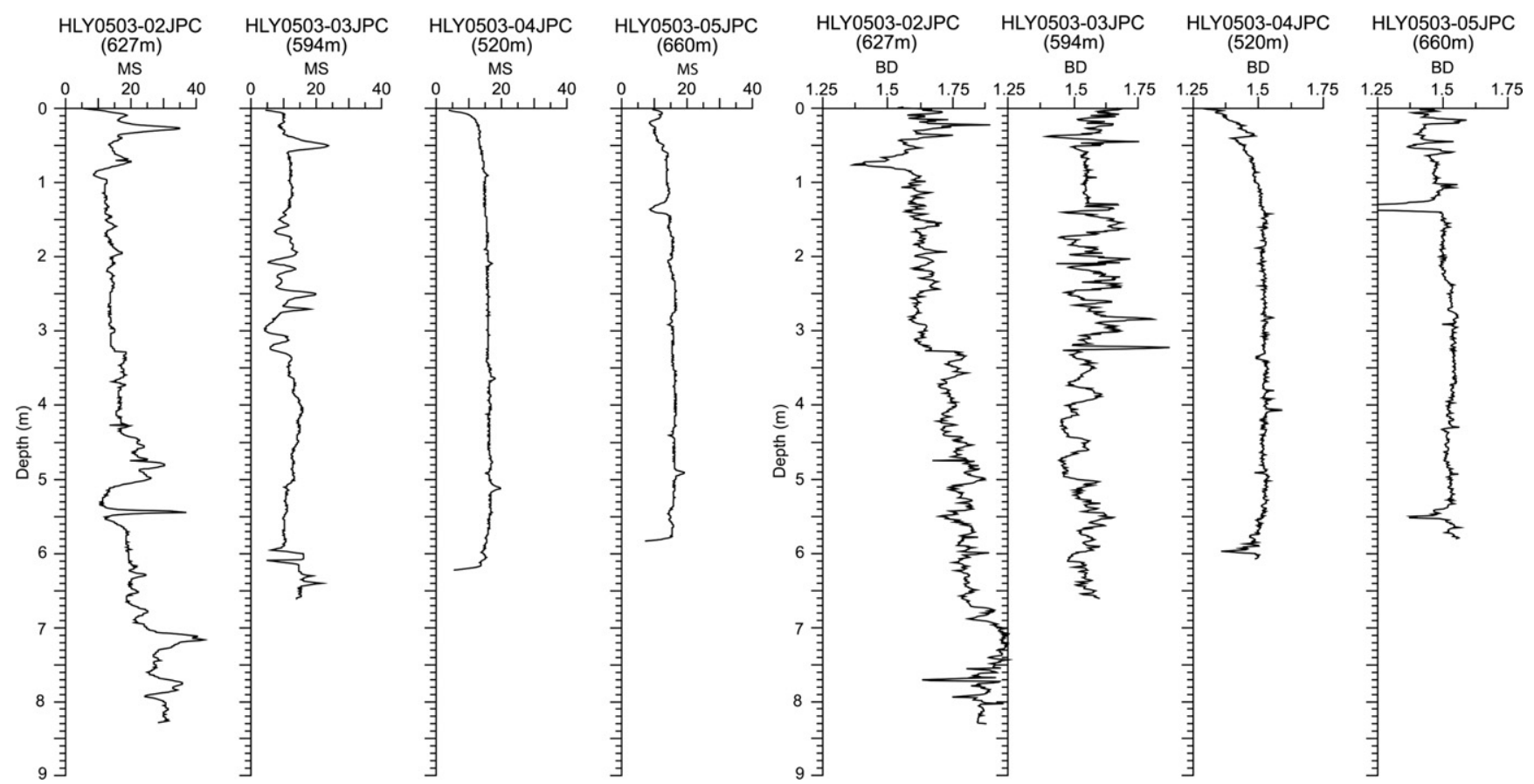

Fig. 3. Magnetic susceptibility (MS $-10^{-5} \mathrm{SI}$ ) and bulk density $\left(\mathrm{BD}-\mathrm{g} / \mathrm{cm}^{3}\right.$ ) for cores 02JPC to 04JPC from the Northwind Ridge and core 05JPC from the Chukchi Plateau.

how well cores can be correlated within different regions and then to construct composite sections, when possible, for comparison between the areas.

Cores 02JPC, 03JPC, and 04JPC were recovered from the Northwind Ridge and 05JPC from the Chukchi Plateau (Fig. 1). The magnetic susceptibility and bulk density records display minor and un-diagnostic downhole variations in cores 04JPC and 05JPC and no correlation could be obtained between them (Fig. 3). 02JPC displays a steep downcore increase in the magnetic susceptibility and bulk density records.

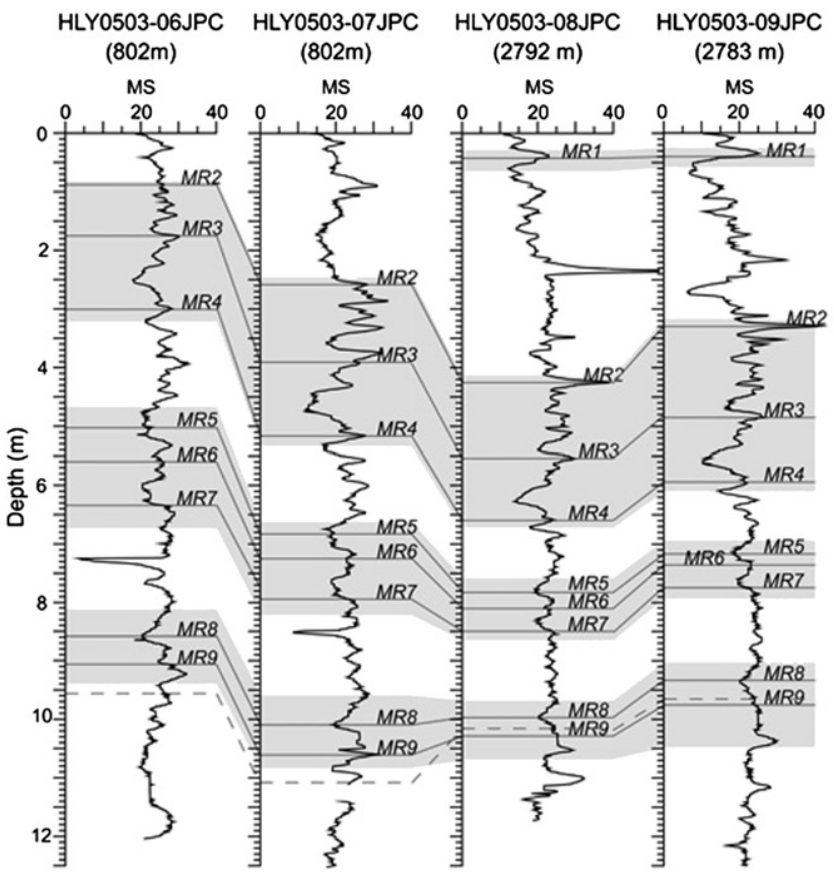

Cores 06JPC and 07JPC were retrieved from a depth of about $800 \mathrm{~m}$ on the southern Mendeleev Ridge, while 08JPC and 09JPC were taken about $170 \mathrm{~km}$ to the north at a water depth of $2800 \mathrm{~m}$ (Fig. 1). In these four cores, nine regional tie points were established (Fig. 4 and Table 2). No lithostratigraphic feature explains the prominent dip in magnetic susceptibility and bulk density between $M R 7$ and MR8 in 06JPC and 07JPC. The large magnetic susceptibility peak in 08JPC with a corresponding dip in bulk density at about $2.3 \mathrm{~m}$ matches an interval with pinkish coarse grains. However neither the peak nor this pinkish layer could be easily recognized in

Fig. 4. Magnetic susceptibility $\left(10^{-5} \mathrm{SI}\right)$ and bulk density $\left(\mathrm{g} / \mathrm{cm}^{3}\right)$ for cores 06JPC to 09JPC from southern Mendeleev Ridge. Gray lines and shaded areas indicate correlation points, dotted gray line indicates an alternative correlation. 


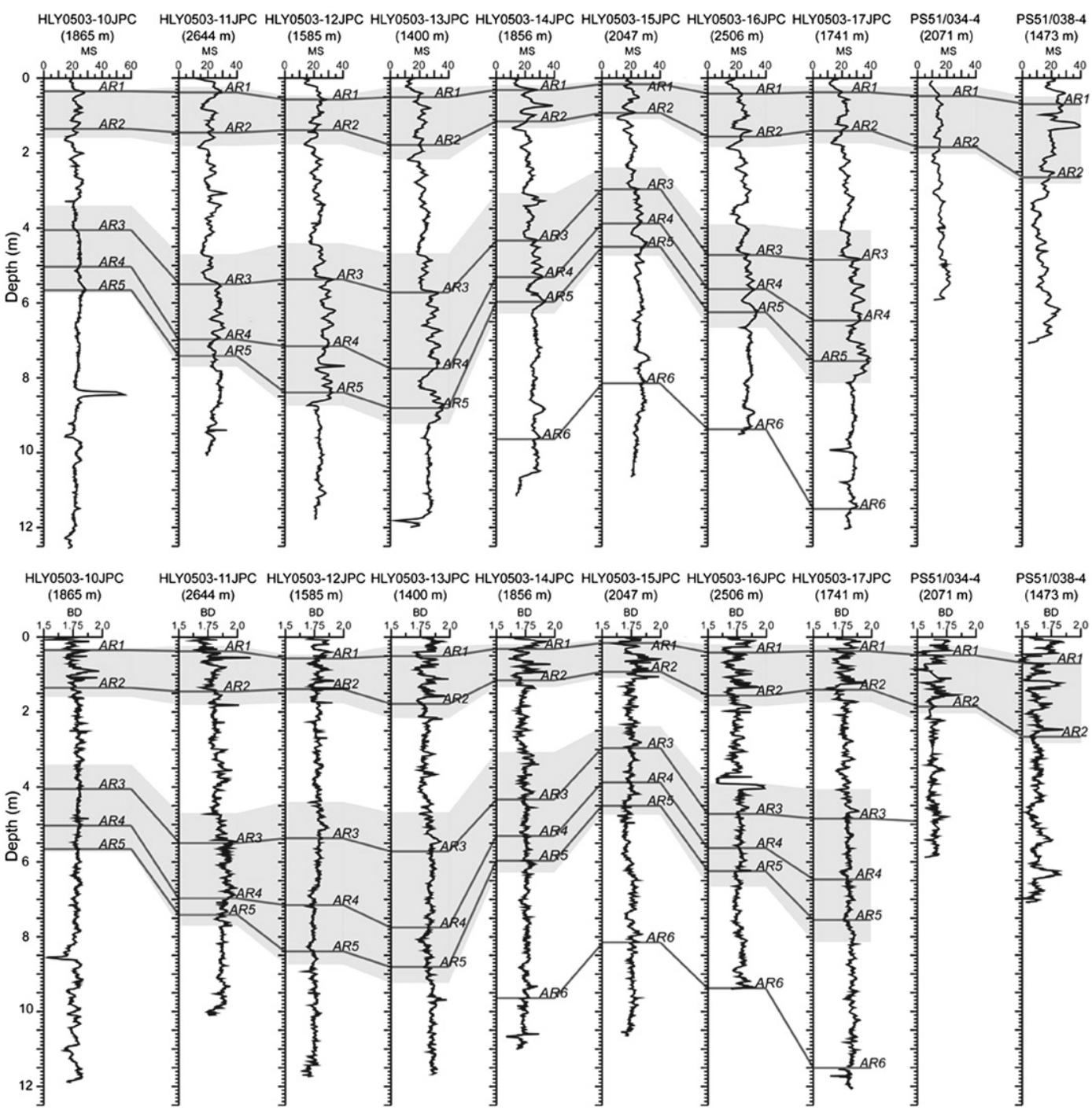

Fig. 5. Magnetic susceptibility $\left(10^{-5} \mathrm{SI}\right)$ and bulk density $\left(\mathrm{g} / \mathrm{cm}^{3}\right)$ for cores 10JPC to 12JPC from northern Mendeleev Ridge, 13JPC to 17JPC, PS51/034-4 and PS51/038-4 (Jokat, 1999a) from the Alpha Ridge, gray lines and shaded areas indicate correlation points.

the other southern Mendeleev Ridge cores. The correlation from the shallower to the deeper cores is not straightforward as the interval above MR2 is different between the cores. Therefore, an alternative correlation of a prominent peak below MR9 in 06JPC has been marked with a dotted line in Fig. 4 . The core description for 07JPC indicated that some of the upper layers are missing and coring disturbance may at least partially explain the lack of correlation towards the top of the cores. Also, an interval between $2.7 \mathrm{~m}$ and $3.5 \mathrm{~m}$ in 08JPC has been interpreted to represent a slump or gravity-flow deposit (Adler et al., 2009). Given the stronger correlations below MR2 this may also reflect an up-core shift towards a more complex depositional regime.

Cores 10JPC to 12JPC from the northern Mendeleev Ridge compared well to cores 13JPC to 17JPC and the uppermost part of cores PS51/034-4 (Jokat, 1999a) and PS51/038-4 (Jokat, 1999a) from the central Alpha Ridge (Figs. 1 and 9). The cores are spread over a large area, with $550 \mathrm{~km}$ separation between 10JPC and 15JPC, and span water depths between $1400 \mathrm{~m}$ for 13JPC and $2644 \mathrm{~m}$ for 11JPC. There are six regional stratigraphic tie points (AR1 to AR6) established for these cores (Fig. 5), where tie point AR6 is only identified in 14JPC to 17JPC. Especially pronounced in this correlation are the tie points $A R 3$ and $A R 4$ that are easily recognizable in all the HOTRAX cores, but are less recognizable in PS51/034-4 and
PS51/038-4. The general lack of correlation below AR2 in PS51/0384 is notable and may indicate an overall change in the processes controlling deposition as one moves north towards the Lomonosov Ridge, where a stronger influence of either the Transpolar drift or Atlantic intermediate water re-circulation may exist. There is no indication in the lithostratigraphic description to explain the major peak in magnetic susceptibility with a subsequent drop in bulk density between 8.4 and $8.6 \mathrm{~m}$ in core 10JPC.

Cores 96/12-1pc (Jakobsson et al., 2001) and PS2185-6 (Spielhagen et al., 2004) from the crest of the central Lomonosov Ridge were previously correlated to the ACEX record by O'Regan et al. (2008). These cores were compared to 18JPC to 20JPC recovered from the Intra Basin (Fig. 1), where eight regional tie points were determined (Fig. 6 and Table 2). However, no correlation was achieved with 19JPC from the inner flank of the Intra Basin, where an eroded core top was noted. In 20JPC, only the tie points $L R 3$ to LR6 were recognized, whereas a good correlation was established between 18JPC and the cores from the ridge crest. The correlations were mainly achieved using the bulk density records and the definition and correlation of $L R 5$ to $L R 7$ are difficult to recognize in the magnetic susceptibility records. Two dips in bulk density, between $L R 5$ and $L R 6$ and below $L R 6$, correspond to two very finegrained peach colored layers. 


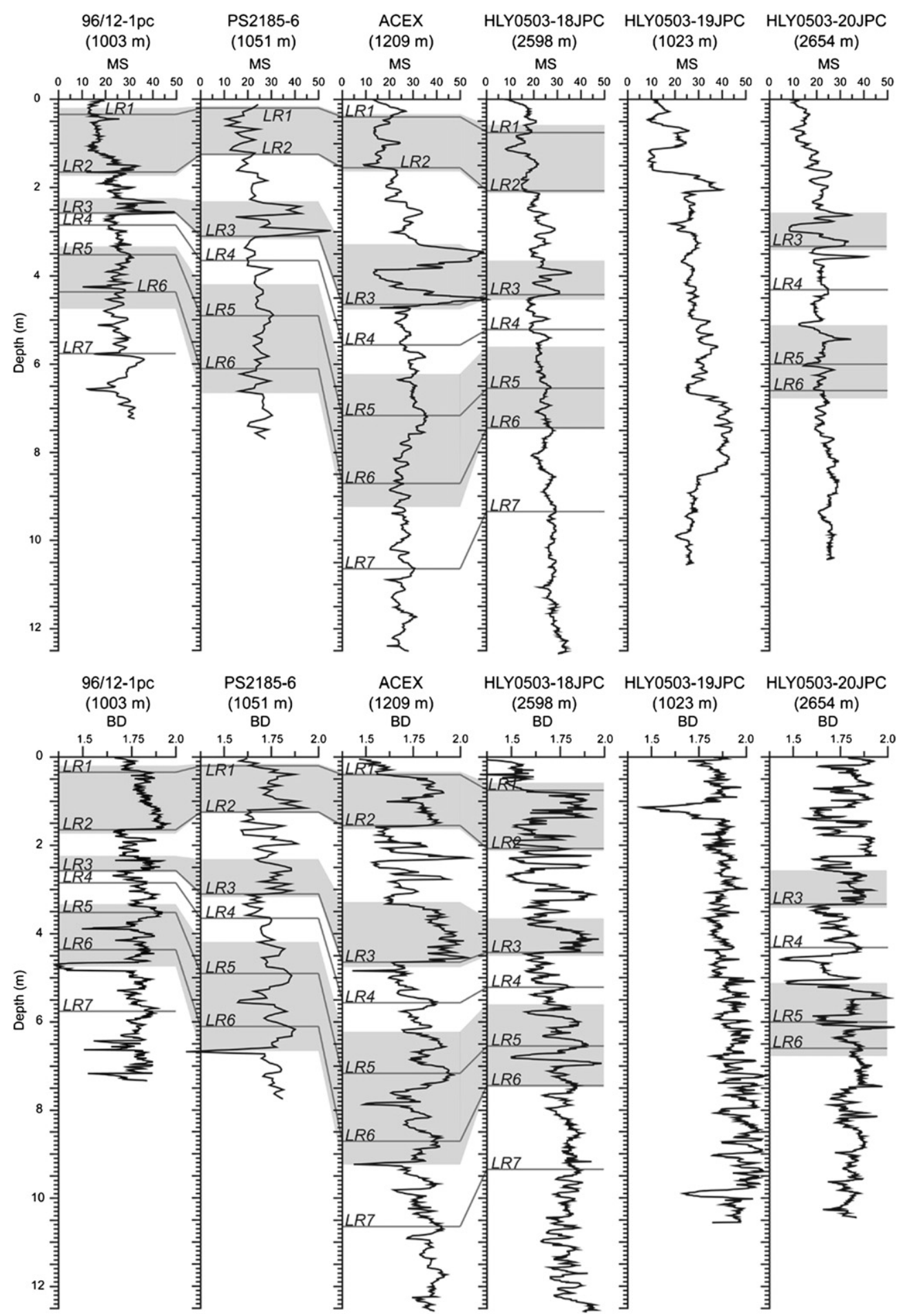

Fig. 6. Magnetic susceptibility ( $10^{-5} \mathrm{SI}$ ) and bulk density $\left(\mathrm{g} / \mathrm{cm}^{3}\right.$ ) for 96/12-1pc (Jakobsson et al., 2001), PS2185-6 (Spielhagen et al., 2004), ACEX composite core (O'Regan et al., 2008) from the Lomonosov Ridge crest, and HOTRAX cores 18JPC to 20JPC from the Lomonosov Ridge Intra Basin. Gray lines and shaded areas indicate correlation points.

The LOMROG cores from the Morris Jesup Rise were taken at about $1000 \mathrm{~m}$ water depth, where GC-09 and GC-10 were situated within an ice scour on the crest of the rise. An additional core, PS2200-5 (Fütterer, 1992; Bergmann, 1996), from 1074 m water depth is also included in the comparison (Fig. 1). A correlation (Fig. 7 and Table 2) between all cores was possible for the upper parts of the records (MJR1 to MJR4). However, the closely spaced $M J R 1$ and MJR2 were not recognized in GC-10 and the erosional horizon in GC-09 and GC-10 prevents further alignment using these cores. Four additional tie points were found between the longer cores PC-07, PC-08 (MJR5 to MJR8).

Two HOTRAX cores 21JPC from the Gakkel Ridge and 22JPC from the Yermak Plateau were compared to PS2213-3 (Fütterer, 1992), PS2213-6 (Bergmann, 1996), PS2123-2 (Knies, 1994), PS55/151-2 (Jokat, 2000) and the composite stratigraphy from ODP Site 911 (ODP 151-911) (Rack et al., 1996) from the southern Yermak Plateau (Fig. 1). The relatively short core 21JPC does not correlate to any of the cores from the Yermak Plateau or other cores included in this 

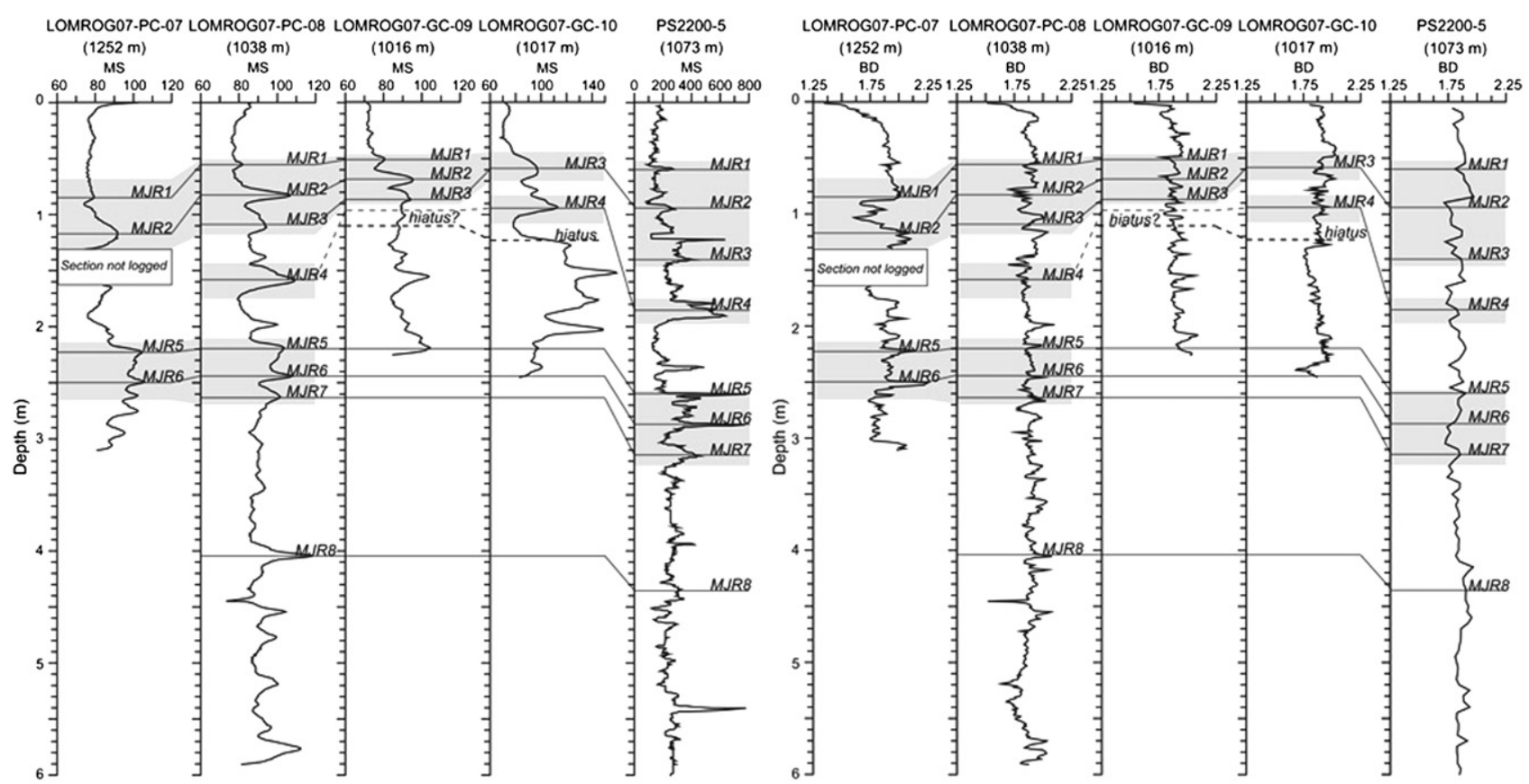

Fig. 7. Magnetic susceptibility $\left(10^{-5} \mathrm{SI}\right)$ and bulk density $\left(\mathrm{g} / \mathrm{cm}^{3}\right)$ for LOMROG cores PC-07, PC-08, GC-09, GC-10 and PS2200-5 (Fütterer, 1992; Bergmann, 1996) from the Morris Jesup Rise. Gray lines and shaded areas indicate correlation tie points.

study. On the Yermak Plateau, a total of six regional tie points (YP1 to YP6) were established between the two longer cores (22JPC and ODP 151-911) and some of the upper tie points were observed in the shorter cores (Fig. 8 and Table 2). The sedimentation rates vary greatly in this area, where tie point YP6 is observed at $11.2 \mathrm{~m}$ in 22JPC and at $22.63 \mathrm{~m}$ in ODP 151-911.

\subsection{Composite stratigraphies}

In five of the identified areas, successful correlations were achieved (Figs. 9 and 10). In the sixth area, the Chukchi Borderland, the lack of correlations among the cores recovered from 520 to $660 \mathrm{~m}$, prevented a composite stratigraphy from being developed. However, a study utilizing visual core descriptions and high-resolution bulk density measurements on undisturbed core material (recovered from 690 to $1917 \mathrm{~m}$ ) from the Northwind Ridge showed a good correlation within the area illustrating a progressive thinning in lithostratigraphic units towards the northern part of the ridge (Phillips and Grantz, 2001). In this section we focus on the composite stratigraphies derived from the five regions within which correlations were established in this study.

The alignment of some of the successfully correlated physical property records is shown in Fig. 10. The averaged depths of lithological layers and key features are included and together with the composite physical property records they form five composite stratigraphies.

\subsubsection{Southern Mendeleev Ridge}

The four HOTRAX cores from the southern Mendeleev Ridge were used to create the composite stratigraphy for the area (Fig. 10, 11 and Table 2). The uppermost $3.5 \mathrm{mcd}$ is interlaminated brown and yellowish brown sandy mud that transitions into a similar less sandy unit. The bottom unit of these cores is mostly dark brown mud with intervals of lighter colored mud. Dark brown to medium brown cycles occur throughout the cores. Magnetic susceptibility peaks MR2 and MR4 occur within dark brown layers in all of the cores and the dips in magnetic susceptibility at $M R 5, M R 7$ and $M R 8$ correspond to medium brown cycles. However, no extensive study of the connection between the brown cycles and magnetic susceptibility or bulk density patterns was undertaken. A pinkish white layer was consistently found at peak MR1 as well as a sand layer that corresponded to the major dip in magnetic susceptibility between MR3 and MR4. The sedimentation rates for these cores are fairly uniform and the average scale factor by which the core depths need to be multiplied to equal the total length of the composite record are all close to 1 (Table 2).

The uppermost $5 \mathrm{~m}$ of the $11.5 \mathrm{~m}$ long core 08JPC was studied further by Adler et al. (2009) and coarse fraction, planktic foraminiferal abundance, paleomagnetic inclination and the developed chronology are included alongside the composite record. The age model for this core is based on paleomagnetic inclination, ${ }^{14} \mathrm{C}$ dating of planktonic foraminifera and foraminiferal stratigraphy. The MIS 6/7 boundary (191 ka, Lisiecki and Raymo, 2005) at about $4.0 \mathrm{~m}$ is equivalent to $2.6 \mathrm{mcd}$, just above tie point MR2 in the composite stratigraphy. This yields an average sedimentation rate of approximately $1.4 \mathrm{~cm} / \mathrm{ka}$. Just below this depth in 08JPC is a peak in foraminiferal abundance as well as the first downhole reversal in the inclination data, interpreted to represent MIS 7. High coarse fraction abundances are found throughout the $5 \mathrm{~m}$ interval studied and published by Adler et al. (2009) although the highest values are found in what is interpreted as MIS 6.

\subsubsection{Northern Mendeleev Ridge and Alpha Ridge}

The composite stratigraphy for the northern Mendeleev Ridge and the Alpha Ridge was constructed from eight HOTRAX cores (10JPC to 17JPC), PS51/034-4 and PS51/038-4 (Figs. 10 and 12, and Table 2). These cores are dominated by interlaminated brown and yellowish brown mud, becoming sandier towards the top and slightly darker downcore. The alternating brown cycles are found in all of the cores. Two dark brown layers correspond to the magnetic susceptibility highs and bulk density lows AR4 and AR5 and a sand layer is consistently found at the magnetic susceptibility dip and bulk density peak below $A R 2$. Core 13JPC has the highest sedimentation rate of the included cores and needs to be compacted by an average factor of 0.78 to fit the total length of the composite record (Table 2).

Additional published data such as coarse fraction, planktic foraminifers, paleomagnetic inclination and an age model for core 

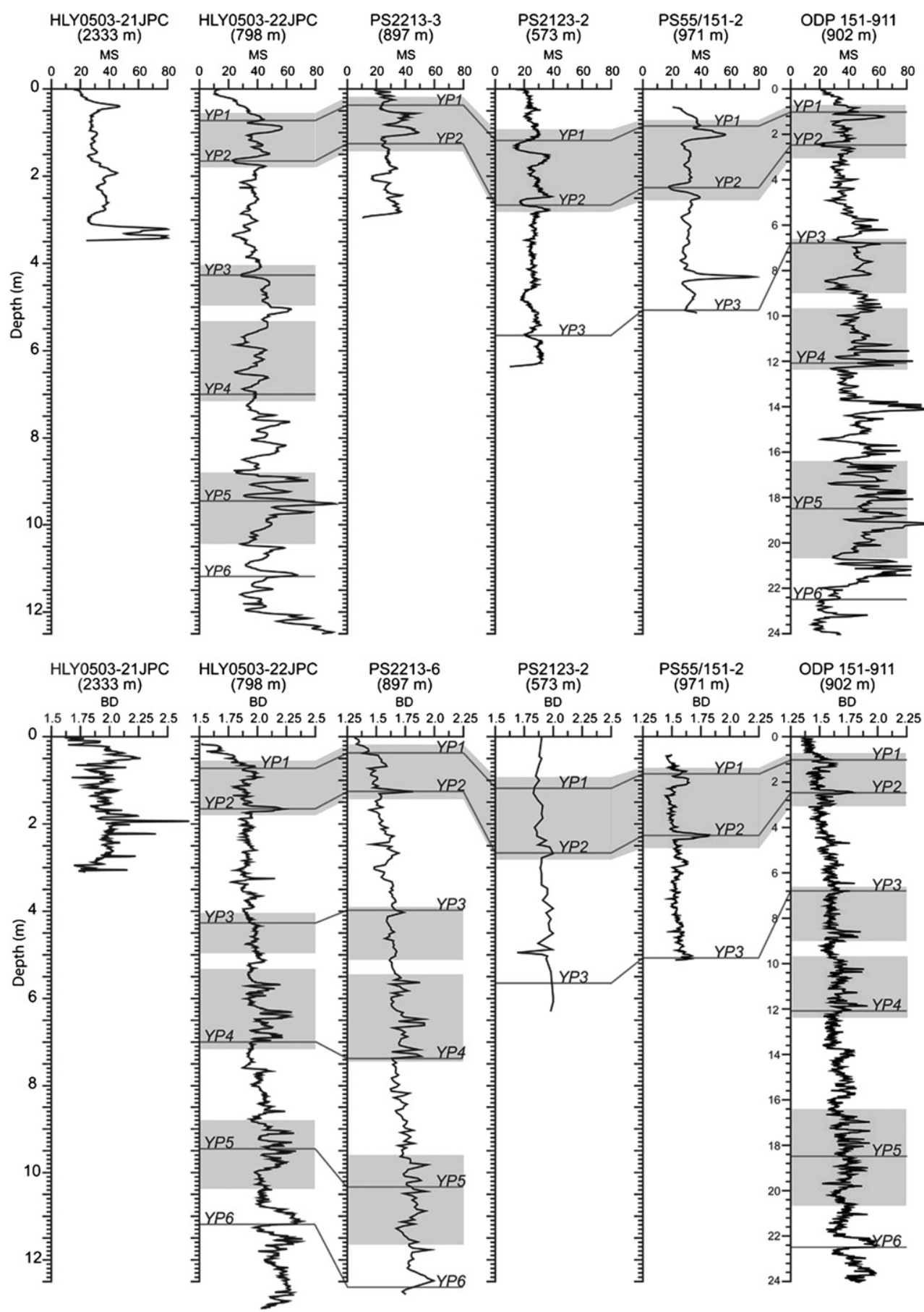

BD

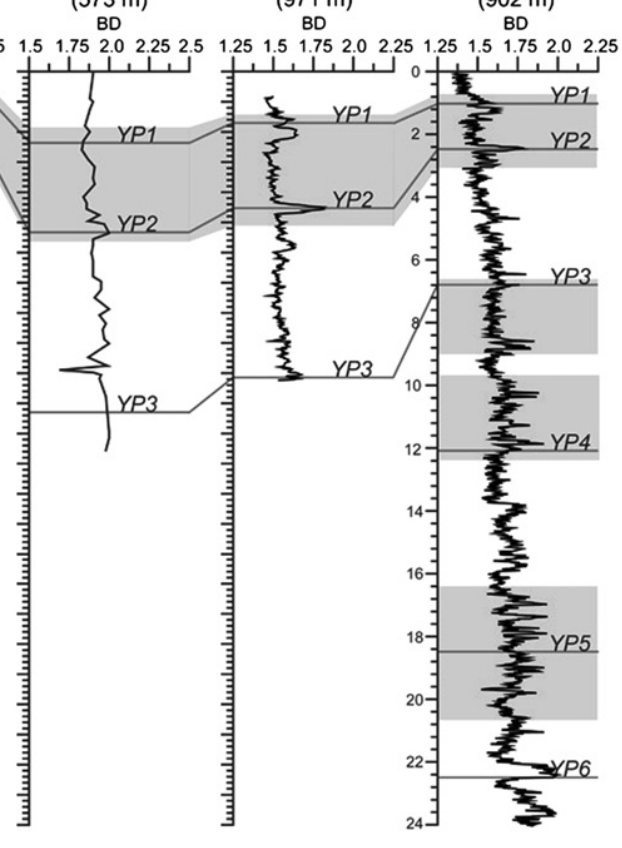

Fig. 8. Magnetic susceptibility $\left(10^{-5} \mathrm{SI}\right)$ and bulk density $\left(\mathrm{g} / \mathrm{cm}^{3}\right)$ for cores 21JPC from the Gakkel Ridge and 22JPC, PS2213-3/6 (Fütterer, 1992; Bergmann, 1996), PS2123-2 (Knies, 1994), PS55/151-2 (Jokat, 2000), and ODP 151-911 (Rack et al., 1996) from the Yermak Plateau. Gray lines and shaded areas indicate correlation points.

PS51/038-4 is included in Fig. 12. This core is $7.19 \mathrm{~m}$ long, however coarse fraction and foraminiferal data is only available for the top $1.7 \mathrm{~m}$ and paleomagnetic inclination data is available down to $2.0 \mathrm{~m}$. The age model is based on paleomagnetic inclination, ${ }^{14} \mathrm{C}$ dating of planktonic foraminifera, biostratigraphy, ${ }^{10} \mathrm{Be}$ and correlations with cores from the Lomonosov Ridge (Spielhagen et al., 2004). The first reversal in paleomagnetic inclination was identified at $1.32 \mathrm{~m}$ within MIS 7 and can be inferred to approximately 1.14 mcd. The MIS 6/7 boundary is identified where there is an upward shift to a higher coarse fraction content and the disappearance of planktic foraminifers at about $1.22 \mathrm{~m}$. This boundary occurs at about 1.00 mcd between tie points $A R 1$ and $A R 2$, which yields an average sedimentation rate of about $0.5 \mathrm{~cm} / \mathrm{ka}$ for the upper meter of the core. The higher variability in bulk density above AR2 (Fig. 5) corresponds broadly to MIS 1 to 6 according to the age model in PS51/038-4.

\subsubsection{Lomonosov Ridge}

Core 18JPC from the Intra Basin, 96/12-1pc, PS2185-6 and the ACEX composite section was included in the composite stratigraphy (Figs. 10 and 13 and Table 2). These cores are made up of an interlaminated brown and yellowish brown sandy mud at the top 


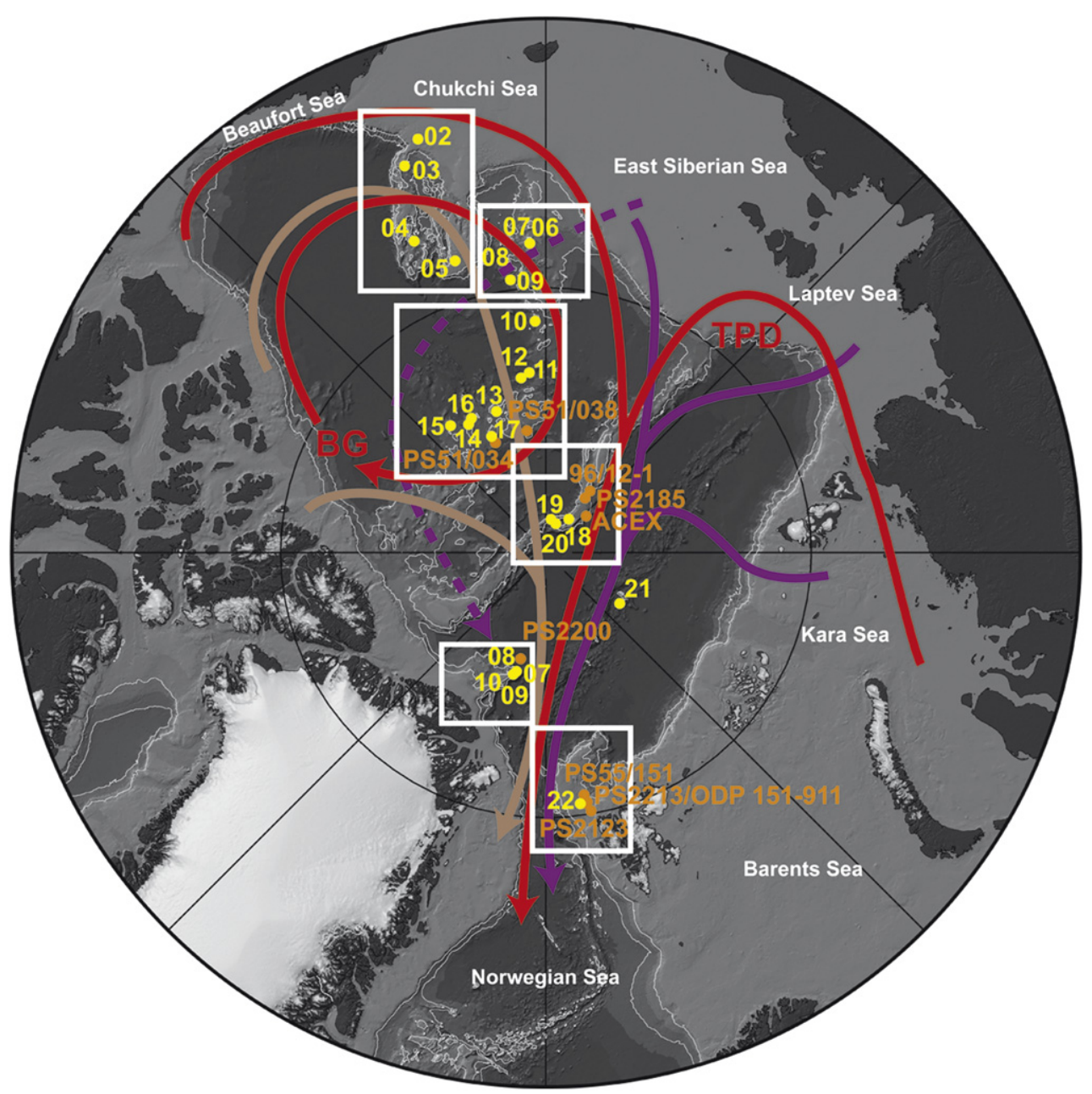

Fig. 9. Schematic map of the Arctic Ocean bathymetry (IBCAO 2.0, Jakobsson et al., 2008a) showing the general sea surface circulation in red (BG-Beaufort Gyre and TPD-Transpolar Drift). North American iceberg driftbrown), Russian pack ice drift in purple and occasional drift of Russian sea ice (dashed purple) during late Pleistocene glacials are shown (Bischof and Darby, 1997). The white rectangles indicate the areas where physical property data has been analyzed together. The core sites for HOTRAX and LOMROG are marked by yellow dots and additional cores used in the composite stratigraphies are marked by orange dots.

and an interlaminated brown and olive brown mud below tie point $L R 3$. Brown cycles are found throughout all of the cores from the Lomonosov Ridge. A gray layer was clearly identified in $96 / 12-1 \mathrm{pc}$ and ACEX and possible gray layers were observed in 18JPC and PS2185-6 just above LR2. Two peach colored layers corresponding to very low bulk density and coarse fraction values were consistently found below LR5 and LR6. The relative sedimentation rates are more variable here than in the two previous areas. The most stretching is required for $96 / 12-1$ pc by a factor of 1.38 and the highest sedimentation rates are observed in the ACEX record (Table 2 ).

The coarse fraction, planktic foraminiferal abundance, paleomagnetic inclination and age model for $96 / 12-1 \mathrm{pc}$ are shown (Jakobsson et al., 2000, 2001). The age model is based on interpretations of nannofossil and foraminiferal abundances, OSL dating and paleomagnetic inclination records (Jakobsson et al., 2001, 2003a). The correlation between this core and the composite stratigraphy indicates that the MIS 6/7 boundary falls at $3.75 \mathrm{mcd}$, slightly below $L R 3$. The average sedimentation rate for cores on the central Lomonosov Ridge would therefore be approximately $2.0 \mathrm{~cm} / \mathrm{ka}$ above this boundary. However O'Regan et al. (2008) and Jakobsson et al., (2000) find lower relative sedimentation rates, closer to $1 \mathrm{~cm} / \mathrm{ka}$, below the MIS 6/7 boundary in both the ACEX record and 96/12-1pc.

\subsubsection{Morris Jesup Rise}

The LOMROG cores PC-07, PC-08, GC-09 and GC-10 from Morris Jesup Rise together with PS2200-5 (Fütterer, 1992) were used to assemble the composite stratigraphy (Figs. 10 and 14 and Table 2). The uppermost unit of interlaminated brown and yellowish brown sandy mud overlies a similarly colored unit of silty mud. Dark brown and medium brown cycles are present all through these cores. A gray layer similar to the gray interval in the Lomonosov Ridge cores is observed between 0.37 and 0.75 mcd and is most prominent in GC-10. A detrital carbonate layer was consistently observed below MJR3 corresponding to a dip in bulk density. The sedimentation rates for the undisturbed cores are similar and little stretching or compacting was necessary to align them (Table 2).

Additional data is included for the $7.25 \mathrm{~m}$ long PS2200-5. The published records of coarse fraction and inclination cover the uppermost $7 \mathrm{~m}$. Planktic foraminiferal abundance data is available down to $4 \mathrm{~m}$. The age model for PS2200-5 relies on paleomagnetic inclination, ${ }^{14} \mathrm{C}$ ages from planktonic foraminifera, biostratigraphy, ${ }^{10} \mathrm{Be}$ and correlations with cores from the Lomonosov Ridge (Spielhagen et al., 2004). The MIS 7.5 (234 ka, Lisiecki and Raymo, 2005) corresponds to a depth in the composite stratigraphy of $3.25 \mathrm{mcd}$, indicating an average sedimentation rate for the Morris Jesup Rise of $1.4 \mathrm{~cm} / \mathrm{ka}$. The interval interpreted as MIS 7 in 

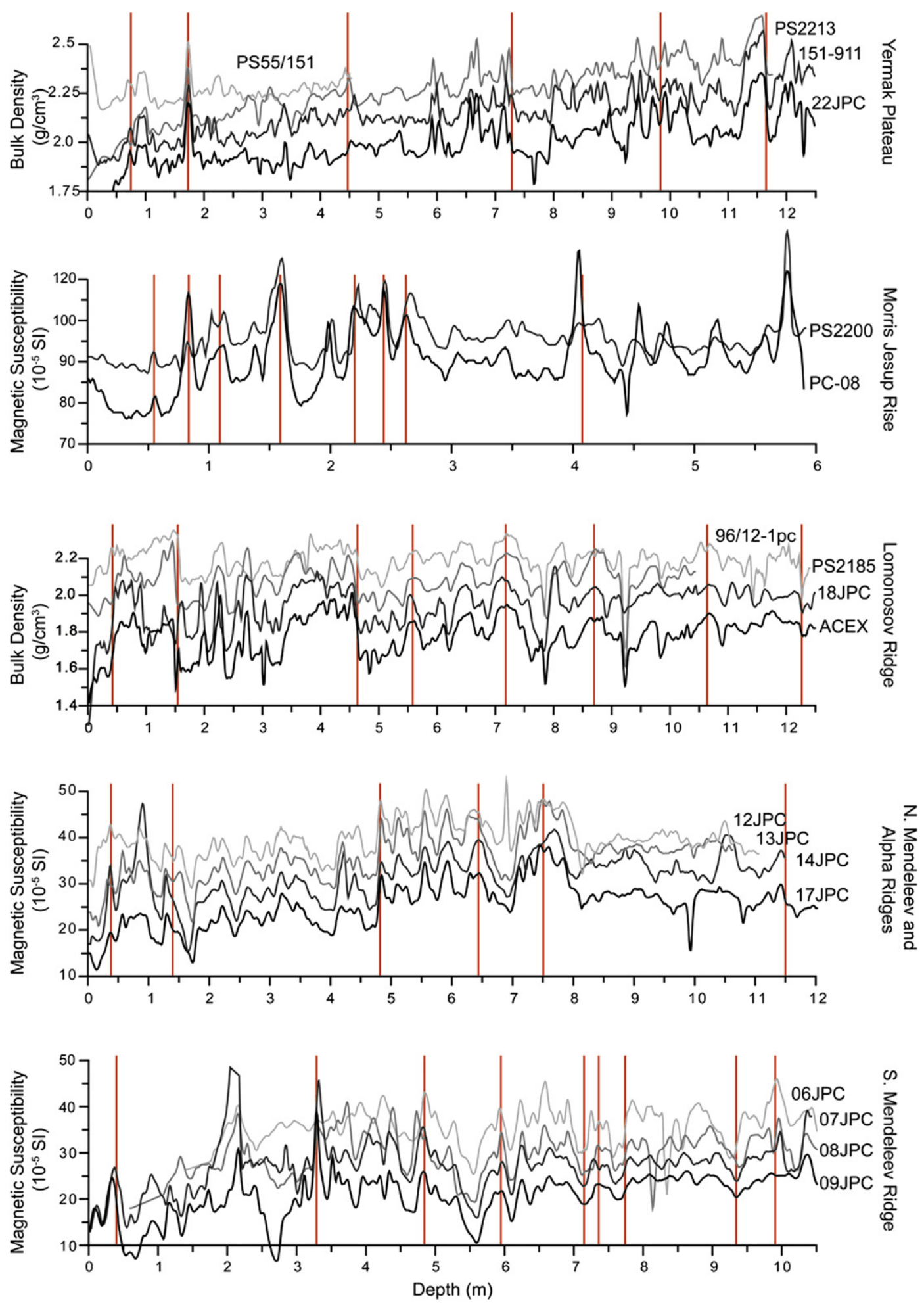

Fig. 10. Physical properties for different cores within the same area stretched to the same depth scale as one of the cores. Here the scales refer to the records marked with a black line.

PS2200-5 incorporates a peak in foraminiferal abundance, the first inclination change and an interval of relatively low coarse fraction content.

\subsubsection{Yermak Plateau}

Two longer cores, 22JPC and the composite section for Site 911 drilled during ODP Leg 151 (Rack et al., 1996), together with the shorter cores PS2213-6 (Bergmann, 1996; Fütterer, 1992), PS2123-2 (Knies, 1994), and PS55/151-2 (Jokat, 2000) were used for the composite stratigraphy for the Yermak Plateau (Figs. 10 and 15 and Table 2). The cores contain mainly grayish brown to yellowish brown sandy, silty mud, although the available lithological descriptions were limited. The average sedimentation rate for the ODP Site 911 record is 


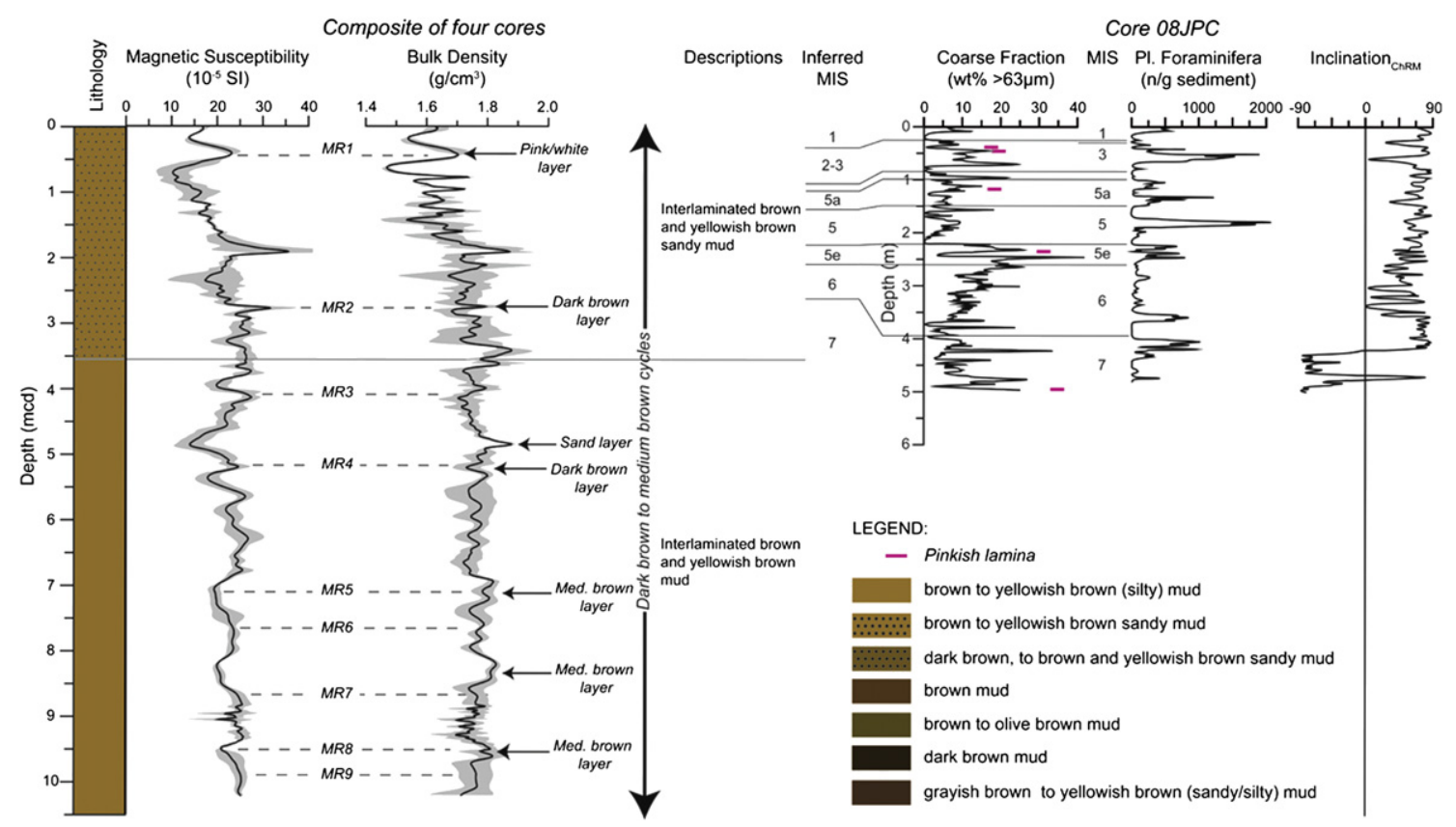

Fig. 11. Composite stratigraphy including general lithostratigraphy (legend for all composites), average magnetic susceptibility and average bulk density for the southern Mendeleev Ridge based on HOTRAX cores 06JPC to 09JPC. The physical property records are plotted with a $5 \mathrm{~cm}$ running mean. The variability of the composite data set within one standard deviation of the mean is shown in gray. Also included are coarse fraction, planktic foraminiferal abundance and inclination data for 08JPC as well as MIS from Adler et al. (2009).

significantly higher than the other cores, requiring compression by a factor of 0.69 to equal the total length of the composite record (Table 2).

The ${ }^{10} \mathrm{Be}$, age and remanent inclination after $40 \mathrm{mT}$ demagnetization for the whole core PS2213-6 (Aldahan et al., 1997;
Schneider, 1996) are included in Fig. 15 , where the ${ }^{10}$ Be record forms the basis for the age model. The MIS $8 / 9$ boundary (300 ka, Lisiecki and Raymo, 2005) can be inferred to $14.55 \mathrm{mcd}$, which results in an average sedimentation rate of $4.8 \mathrm{~cm} / \mathrm{ka}$, which is the highest of all included areas.

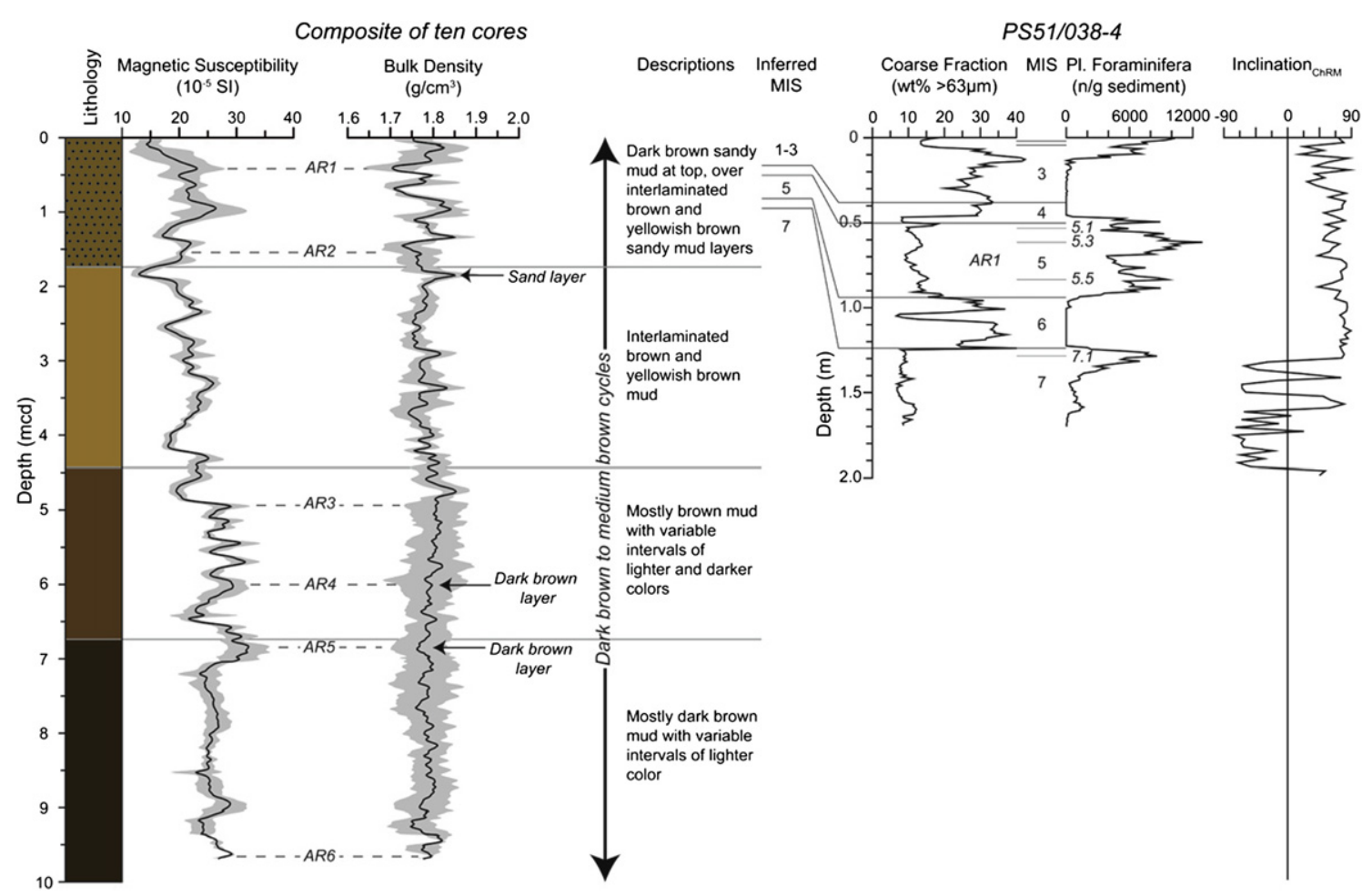

Fig. 12. Composite stratigraphy including general lithostratigraphy (for legend see Fig. 11), average magnetic susceptibility and average bulk density for the northern Mendeleev Ridge and Alpha Ridge based on HOTRAX cores 10JPC to 17JPC, PS51/034 and PS51/038 (Jokat, 1999a). The physical property records are plotted with a $5 \mathrm{~cm}$ running mean. The variability of the composite data set within one standard deviation of the mean is shown in gray. Also included are coarse fraction, planktic foraminiferal abundance, inclination data and MIS for PS51/038-4 (Spielhagen et al., 2004). 

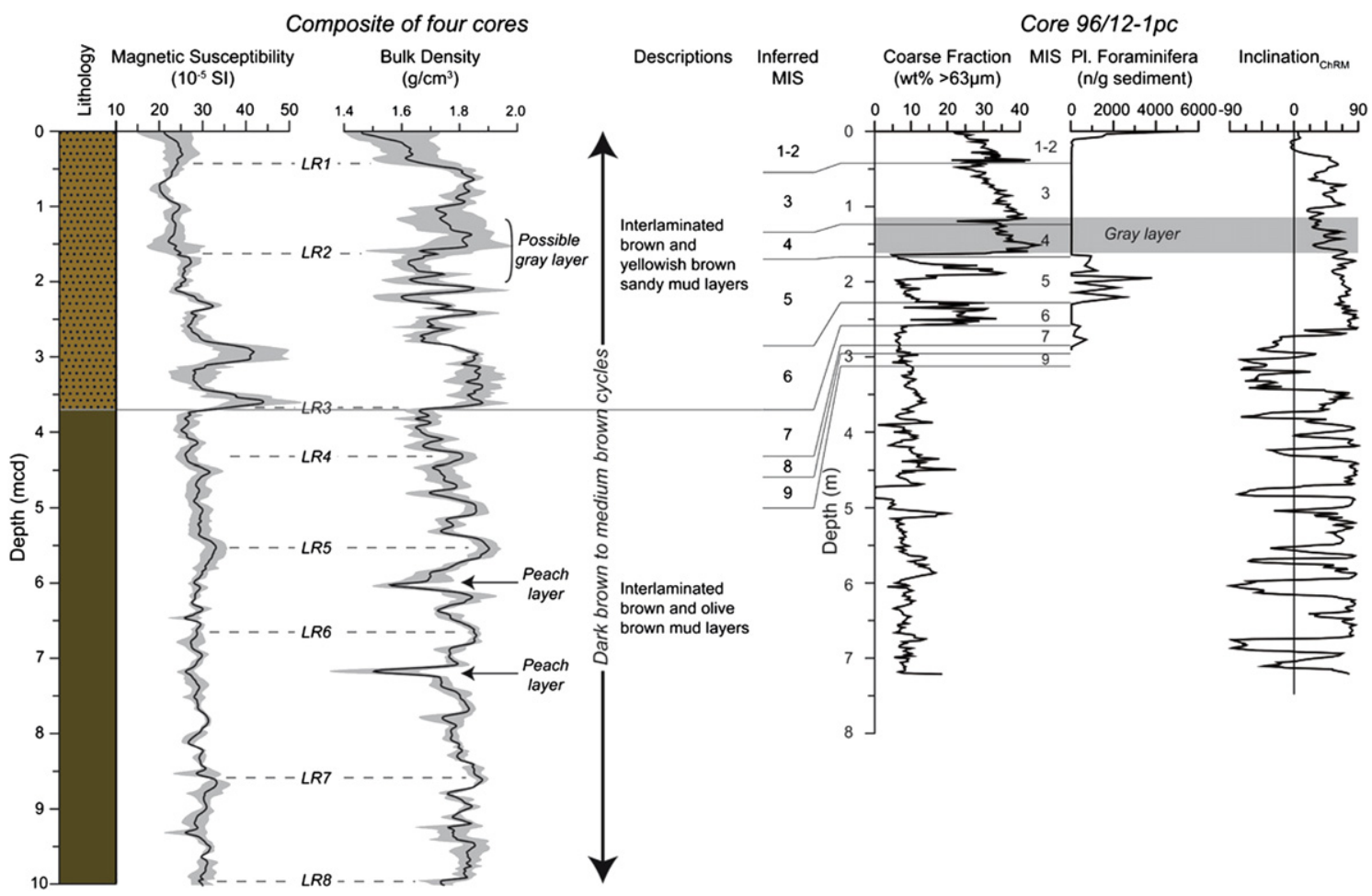

Fig. 13. Composite stratigraphy including general lithostratigraphy (for legend see Fig. 11), average magnetic susceptibility and average bulk density for the Lomonosov Ridge based on HOTRAX core 18JPC, 96/12-pc (Jakobsson et al., 2001), PS2185-6 (Spielhagen et al., 2004) and ACEX drill core (O'Regan et al., 2008). The physical property records are plotted with a $5 \mathrm{~cm}$ running mean. The variability of the composite data set within one standard deviation of the mean is shown in gray. Also included are coarse fraction, planktic foraminiferal abundance, MIS and inclination data for 96/12-1pc (Jakobsson et al., 2001).

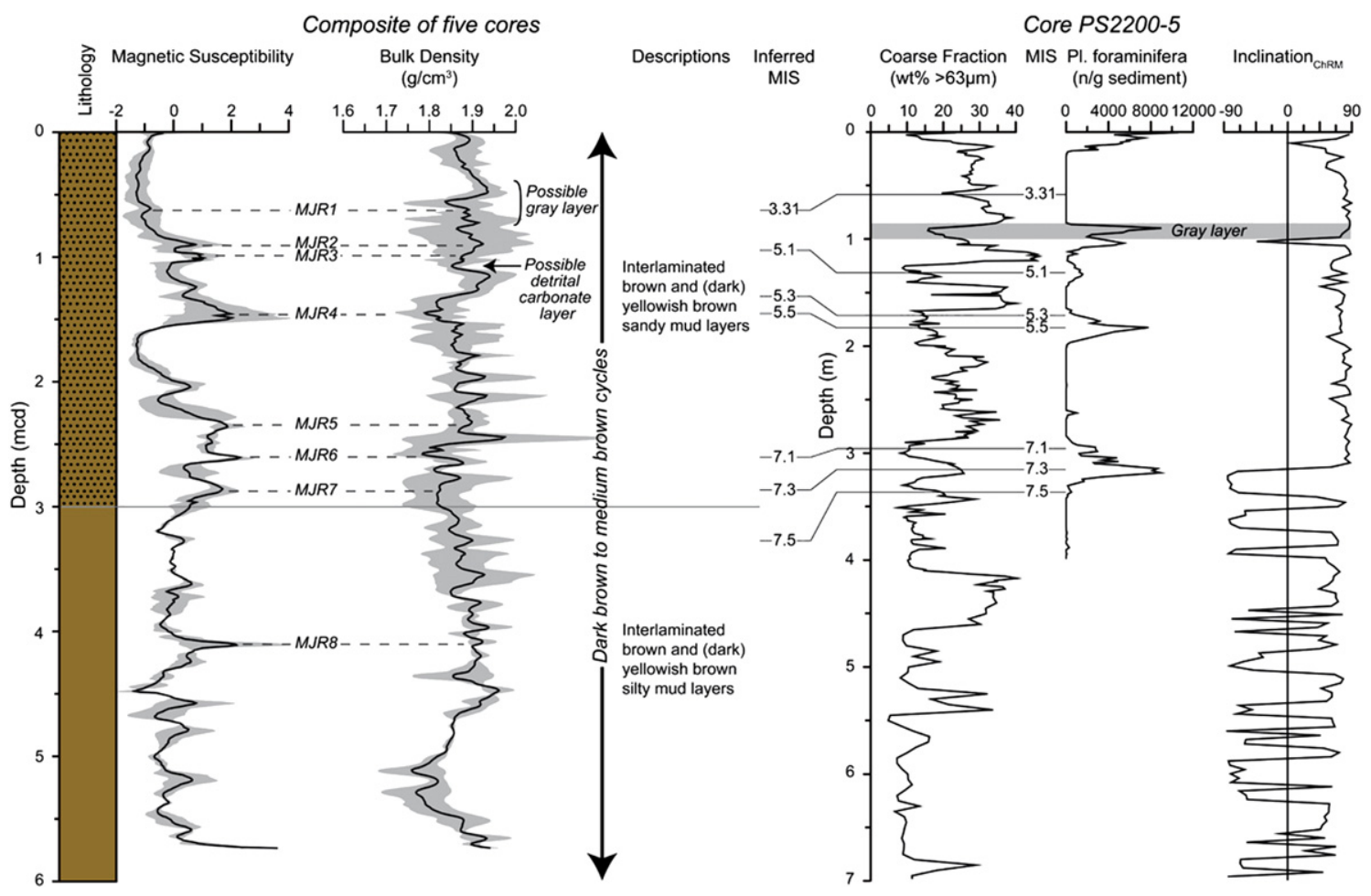

Fig. 14. Composite stratigraphy including general lithostratigraphy (for legend see Fig. 11), average magnetic susceptibility and average bulk density for the Morris Jesup Rise based on PS2200-5 (Bergmann, 1996; Fütterer, 1992) and LOMROG cores PC-07, PC-08, GC-09 and GC-10. The magnetic susceptibility record is plotted on a standardized scale to account for differences in sensitivity of the measurements and both physical properties are plotted with a $5 \mathrm{~cm}$ running mean. The variability of the composite data set within one standard deviation of the mean is shown in gray. Also included are coarse fraction, MIS, planktic foraminiferal abundance and inclination data for PS2200-5 (Spielhagen et al., 2004). 

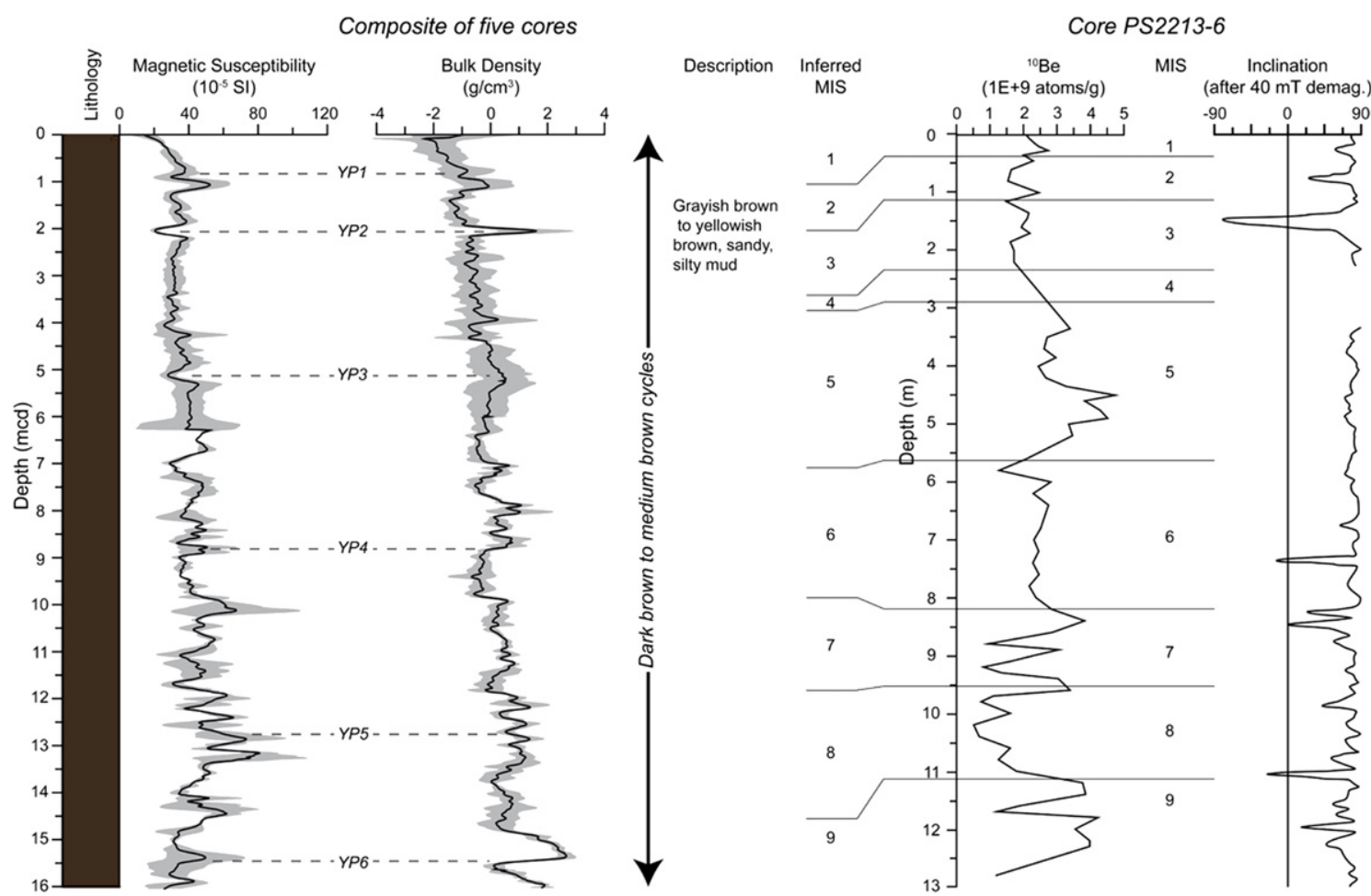

Fig. 15. Composite stratigraphy including general lithostratigraphy (for legend see Fig. 11), average magnetic susceptibility and average bulk density for the Yermak Plateau based on 22JPC, PS2213-3/6 (Bergmann, 1996; Fütterer, 1992), ODP core 151-911 (Rack et al., 1996), PS55/151-2 (Jokat, 2000), and PS2123-2 (Knies, 1994). The bulk density record is plotted on a standardized scale to account for differences in sensitivity of the measurements and both physical properties are plotted with a $5 \mathrm{~cm}$ running mean. The variability of the composite data set within one standard deviation of the mean is shown in gray. Also included are ${ }^{10} \mathrm{Be}$, age and remanent inclination after 40 mT demagnetization for PS2213-6 (Schneider, 1996; Aldahan et al., 1997). Note the different depth scales for the two records.

\section{Discussion}

The standard lithostratigraphic units (A-M) established by Clark et al. (1980) from Amerasian Basin cores were based on lithostratigraphic features such as prominent sand layers and pinkish white carbonate layers. Although these units have been observed in numerous cores from the Alpha and Mendeleev ridges (Clark et al., 1990; Jokat, 1999b; Minicucci and Clark, 1983; Mudie and Blasco, 1985), we are not able to unequivocally identify them in our HOTRAX cores or other records retrieved from the Lomonosov Ridge and the Eurasian Basin (Sellén et al., 2008). There are, however, some lithostratigraphic components from Clark et al. (1980) that are possible to identify in cores from the Alpha and Mendeleev ridges, such as prominent carbonate layers.

The use of physical properties as a tool for stratigraphically aligning cores from different holes and sites is consistently applied within the scientific Ocean Drilling community. This forms the basis for constructing a 'composite' stratigraphic section from overlapping cores recovered in multiple holes. Detailed age models are then constructed through direct or relative dating techniques. Here, we apply the same principles and test to what spatial extent they are applicable within the Arctic Ocean. A lack of correlatable features between two or more records can be due to many depositional and post-depositional processes, but a reliable correlation is a powerful argument for the existence of similar depositional systems when these changes do co-vary through time across large spatial distances (i.e. between cores). The composite stratigraphies, constructed based on similar variations in physical properties, provide a less subjective approach than using lithostratigraphy alone and may contribute to a more robust framework for developing and interpreting chronologies within individual depositional areas and across the Arctic Ocean. As more sediment cores are retrieved from the Arctic Ocean, and more analyses are made, additional information may be added to revise the composite stratigraphies. This also applies to additional data such as detailed proxies for sediment source and composition, potentially available through analysis of XRF-scanning data.

\subsection{Possible circulation and provenance controls on stratigraphy}

The close correlation of the physical property data within individual physiographic regions generally illustrates spatially consistent depositional patterns through the later part of the Quaternary. The highest average sedimentation rate is observed in the Yermak Plateau composite record, although there is large variability between the cores in this region. The spatial correlation was limited and cores from the northern part of the plateau and from the flank, such as ODP Site 912, could not be unambiguously linked to the composite stratigraphy. Regional sedimentary patterns may be affected by variable sediment input from the Svalbard continental shelf via sea ice and icebergs, irregular bathymetry and extensive ice erosion in the shallower areas (Vogt et al., 1994; Jakobsson et al., this issue). Additionally, the core sites are also situated within the inflow path of Atlantic waters (Dowdeswell et al., this issue), which must exert a strong influence on sediment deposition.

The intermediate Atlantic waters continue from the Yermak Plateau along the continental slope of the Barents-Kara Sea before turning with one path following the Lomonosov Ridge. Finegrained sediment from the shelf edge may become suspended and transported to the center of the Lomonosov Ridge (Fahl and Nöthig, 2007), although the magnitude of this transport mechanism is uncertain. Sea ice transported by the Transpolar Drift carries material from the Siberian shelf, mostly from the Laptev Sea, over the Lomonosov Ridge towards the Fram Strait. Although, the central 
Lomonosov Ridge receives ice rafted material from both the Eurasian and the Amerasian side of the ridge (Fig. 9) (Bischof and Darby, 1997). According to our results, the Lomonosov Ridge cores have the second highest sedimentation rates in the Arctic Ocean. This may be due to the combined accumulation of sediment transported within both the Beaufort Gyre and the Transpolar Drift. Core 18JPC from the Intra Basin is closely linked to the cores from the ridge crest, indicating that the same sedimentation regime exists, despite being located in different water masses. The poor correlation to the other two cores (19JPC and 20JPC) from the Intra Basin arises from dynamic circulation and reworking of sediment within this basin (Björk et al., 2007).

Some of the Atlantic derived intermediate water spills over the Lomonosov Ridge and flows into the Makarov Basin. Cores located between the Lomonosov Ridge and Alpha Ridge exhibit a slightly higher sedimentation rate than the cores found further into the Canada Basin (Fig. 5). PS51/038-4 is located closest to the Lomonosov Ridge and cannot be correlated to the northern Mendeleev Ridge and Alpha Ridge HOTRAX cores below tie point AR2. However, this core has been linked to PS2185- 6 by Spielhagen et al. (2004) by coarse fraction content and planktic foraminiferal abundances. This core may therefore be located in a transitional zone between two depositional regimes. The average sedimentation rate for the cores on the Alpha Ridge and northern Mendeleev Ridge are the lowest in the Arctic Ocean and may be a result of the location within the Beaufort Gyre. The cores receive material from sea ice and icebergs carried within the sluggish gyre and potentially deliver less sediment due to lower rates of melting.

The southern Mendeleev Ridge composite stratigraphy has intermediate sedimentation rates and likely receives more material from the continental shelves and the adjacent Chukchi Plateau via current transport. The melting of sea ice during summers is also more pronounced closer to the shelf edge than in the central part of the ocean basin (Comiso et al., 2008). The sediment sources of the East Siberian Sea and the Laptev Sea influence both the Mendeleev Ridge and the Alpha Ridge, but large differences in sedimentation rates make any physical property based correlation difficult. Additionally, icebergs derived from the Laurentide Ice Sheet may not have reached the southern Mendeleev Ridge to the same extent as the northern part of the ridge (Fig. 9) (Bischof and Darby, 1997).

The sediment records from the Chukchi Borderland appear heavily affected by glaciogenic processes (Jakobsson et al., 2005; Polyak et al., 2007). The flat downhole density profiles in cores 04JPC and 05JPC are either due to coring disturbance, icegrounding resulting in homogenization of the sediment from reworking, or represent rapid deposition. The record for 02JPC, which is from a depth and region where mega-scale lineations are present (Jakobsson et al., 2005), has a steep downhole density gradient suggesting erosion or sub-glacial deformation.

The Morris Jesup Rise should record both the Amerasian Basin and Eurasian Basin signal as sediment incorporated in sea ice from the Beaufort Gyre and the Transpolar Drift affects the area. The notable presence of dolomite in core PS2200-5 confirms that sediment from the Canadian Arctic Archipelago or northern Greenland accumulates on the rise (Darby, 1971; Vogt, 1997). Similarly, the waters flowing across the rise are a mixture of Amerasian Basin and Amundsen Basin intermediate waters, possibly bringing suspended sediment from both sides of the Lomonosov Ridge. The Morris Jesup Rise sedimentation regime has similar intermediate sedimentation rates as the southern Mendeleev Ridge and is similarly close to a continental shelf source. The lower average sedimentation rates, when compared to the central Lomonosov Ridge, may be attributed to the distance that sea ice has to travel before reaching this location, or a reduction in the amount of melting that occurs in this setting. Ice-grounding on the Morris Jesup Rise, recorded in GC-09 and GC-10 has been precisely identified in these cores and dated to pre-MIS 5.5 (Jakobsson et al., this issue). This implies that the ice-grounding on the Morris Jesup Rise took place during MIS 6, at the same time as grounding events dated on the central Lomonosov Ridge (Jakobsson et al., 2001; Jakobsson et al., 2008c).

\subsection{Links between composite stratigraphies}

As we have shown, there are at least five physiographic regions in the central Arctic Ocean, characterized by similar depositional patterns. However, a key question remains as to whether useful stratigraphic links exist between these regions. There are three notable markers that could potentially be used as stratigraphic/ chronostratigraphic tie points between the composite sections (Fig. 16).

One of the most conspicuous changes in any of the composite stratigraphies is the clear shift towards a re-current coarse-grained facies that characterize the last two glacial cycles on the Lomonosov Ridge. The longer ACEX record shows that this pattern is not observed previously in the Quaternary sediment record (O'Regan et al., 2009). This change in depositional mode has been linked by Spielhagen et al. (2004) to terrestrial reconstructions of the Barents-Kara ice sheet (Svendsen et al., 2004). The input of large amounts of coarse-grained material is tentatively tied to the marine based part of this ice sheet in the Kara Sea (Jakobsson et al., 2001; Haley et al., 2008). Whether or not this increase in coarse fraction abundance on the Lomonosov Ridge is solely caused by the BarentsKara ice sheet remains an open question. A reconstruction of the Kara ice sheet indicates that there have been major glacial events during at least two earlier Pleistocene glaciations (Möller et al., 2006), which challenges arguments for a local origin of the grain size shift at MIS 6/7 on the Lomonosov Ridge.

Similar changes in the abundance of coarse fraction material can be observed in core PS2200-5 from the Morris Jesup Rise since MIS 6 (Spielhagen et al., 2004), however, there is no general shift to coarser grain sizes at MIS 6/7 boundary, which may be due to its relative proximity to the Greenland continental shelf. In the Amerasian basin cores, a coarse-grained interval dated to MIS 6 is consistently observed in published grain size records. In 08JPC from the southern Mendeleev Ridge, this does not seem to represent a comparable shift in the long-term abundance of coarse-grained material since MIS 6. PS51/038-4 from the Alpha Ridge shows an apparently dramatic increase in the coarse fraction abundance at the MIS 6/7 boundary, but long grain size records are largely lacking. Therefore, while MIS 6 sediments often appear to be enriched in coarse material, it is only on the central Lomonosov Ridge that this occurs uniquely in MIS 6 or younger sediments. However, a potential problem when interpreting grain size records from low sedimentation rate regimes in the Amerasian Basin is the influence of authigenic precipitates of Fe-Mn nodules. Clark et al. (1990) show that $20-30 \%$ of the coarse fraction content in sediment from the northern Alpha Ridge is composed of these authigenic minerals. Accounting for the auhtigenic component of the coarse fraction material would facilitate comparing the downhole changes in grain size between these regions.

A more obvious stratigraphic marker may be the first prominent paleomagnetic inclination change. This change is observed on the Mendeleev Ridge, Alpha Ridge, Lomonosov Ridge and Morris Jesup Rise (Jakobsson et al., 2000; Spielhagen et al., 2004; O'Regan et al., 2008; Polyak et al., 2009) (Fig. 16), and is consistently used to-date the MIS 6/7 transition. In many of the analyzed cores where this inclination shift is recognized, there are independent chronostratigraphic data that confirm an age at least older than MIS 5 and most likely older than MIS 6. This evidence includes amino acid racemization (08JPC and 96/12-1pc, Kaufman et al., 2008); OSL 

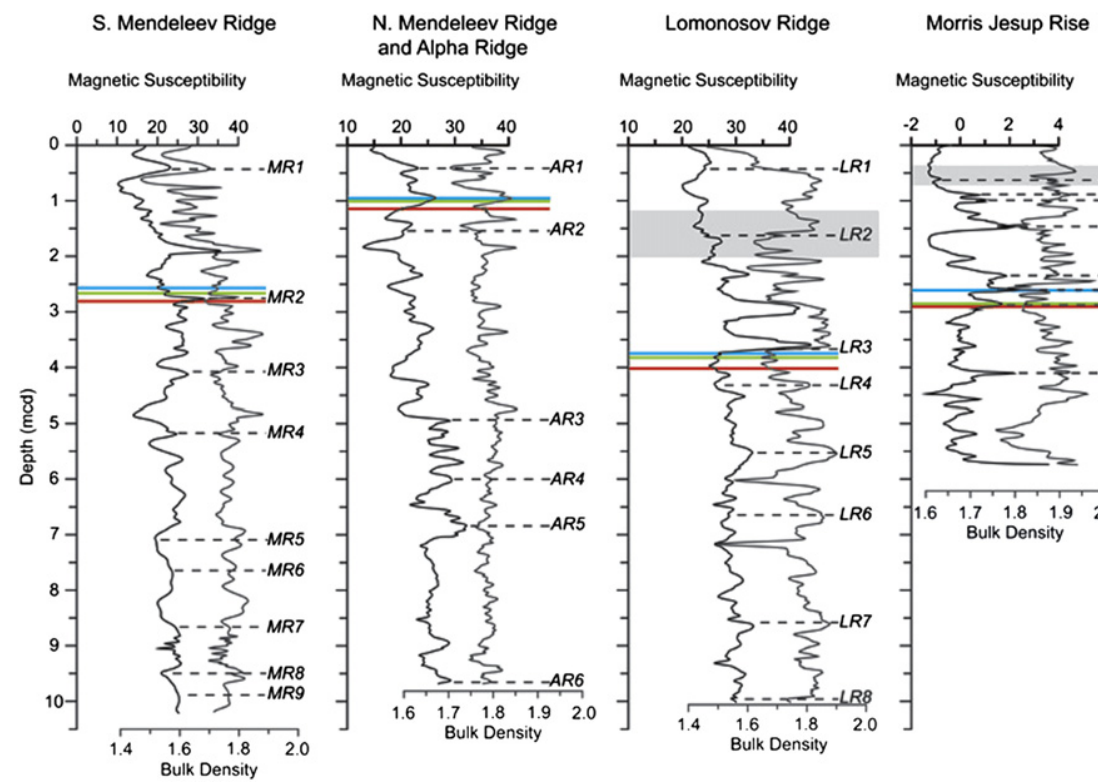

Yermak Plateau

Magnetic Susceptibility

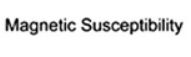

Magnetic Susceptibility
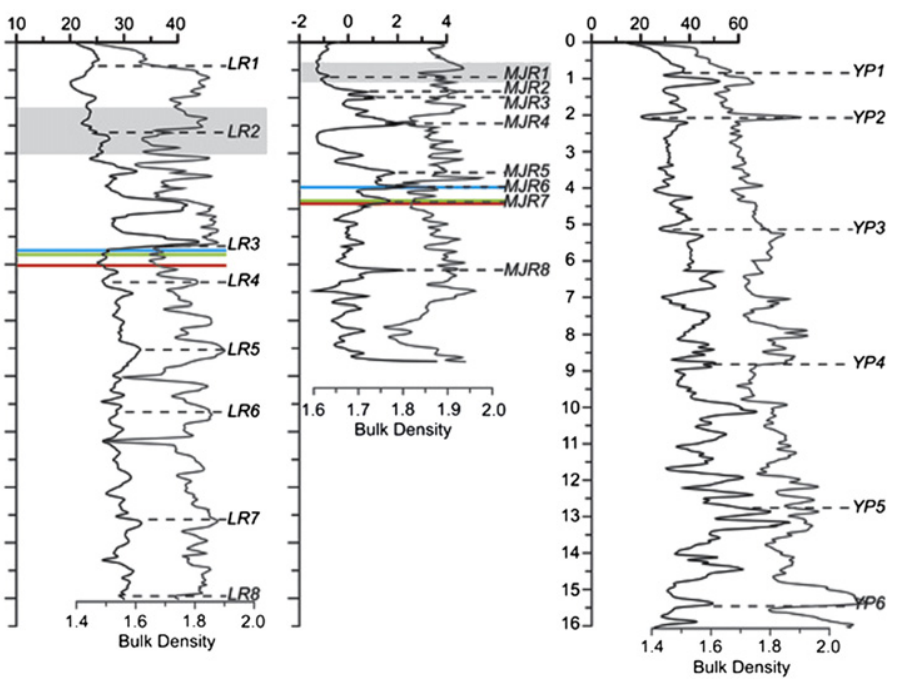

Fig. 16. Comparison of composite magnetic susceptibility $\left(10^{-5} \mathrm{SI}\right)$ and bulk density $\left(\mathrm{g} / \mathrm{cm}^{3}\right)$ records and potential correlation points based on a shift to coarser grains at MIS $6 / 7$ (blue), foraminiferal peak at MIS 7.1 (green) and first paleomagnetic inclination change (red). The position of the gray layer has been marked for the Lomonosov Ridge and the Morris Jesup Rise composite stratigraphies.

dating (96/12-1pc, Jakobsson et al., 2003a); diagnostic calcareous nannofossil assemblage and abundance data (see the summary in Backman et al., 2009), and the basin-wide restricted occurrence of the benthic foraminifera Bulimina aculeata in MIS 5.1 (96/12-1pc, Jakobsson et al., 2001; GreenIce 10, Nørgaard-Pedersen et al., 2007; NP-26 cores, Polyak et al., 2004; NWR 5, Poore et al., 1994) and Pullenia spp in MIS 7 (96/12-1pc and NWR 5, Backman et al., 2004).

A recent study of the magnetic mineralogy of HOTRAX core 06JPC from the southern Mendeleev Ridge offers insights into the cause of the recognized anomalous paleomagnetic inclination data recorded in many cores from the Arctic Ocean. Channell and Xuan (2009) show that the paleomagnetic stratigraphy of this core is likely affected by oxidation processes that result in the development of so-called self-reversals. They propose that titanomagnetities are transformed to titanomaghematites during seafloor oxidation events in areas with low sedimentation rates, which acquire a chemical remnant magnetization that is partially selfreversed and not resolvable using alternating field demagnetization techniques. Channell and Xuan (2009) suggest that changes in the amount and type of organic matter delivered to the seafloor may be one explanation for the apparent basin-wide correlation of these long-duration negative excursions (Spielhagen et al., 2004; O'Regan et al., 2008). Another possibility is that variations in the inflow of Atlantic, Pacific and freshwater affects the ventilation of the basin on glacial-interglacial timescales. Whether the inclination changes record the time-dependant behavior of the geomagnetic field, or the ventilation conditions within the Arctic Ocean, both possibilities provide useful stratigraphic and/or paleoceanographic information. The absence of the anomalous excursional behavior in sediment younger than MIS 6/7 suggests a rather fundamental and basin-wide change in paleoceanographic conditions, organic carbon delivery and/or overall sedimentation rates.

The third boundary that may be used for correlation is the last prominent peak in planktic calcareous foraminiferal abundance (Fig. 16). However, recent results show that even within the central Lomonosov Ridge the preservation of calcareous foraminifers may vary from core to core. In the ACEX record, planktic foraminifers from MIS 9 were observed (Cronin et al., 2008), whereas in 18JPC from the Intra Basin only calcareous foraminifers from MIS 3 are preserved (Hanslik et al., this issue). In order to use planktic foraminiferal peaks for correlation, the age of the lowermost peak must be firmly established. Where the resolution does not allow distinguishing between MIS 7 interstadials, we assume that the lowermost foraminiferal peak corresponds to MIS 7.1, and this is consistently observed between the coarse fraction shift and the first inclination change (Fig. 16).

A potential fourth stratigraphic marker may be the prominent gray unit identified on both the central Lomonosov Ridge (Jakobsson et al., 2001) and the Morris Jesup Rise, but assumes that this unit originates from a particular event in time and requires additional work on the mechanism driving the diagnostic color change in the sediments. A correlation between the Morris Jesup Rise and the Lomonosov Ridge based on this layer indicates higher sedimentation rates on the Lomonosov Ridge, which is consistent with previous stratigraphic links (Fig. 16).

Perhaps one of the most interesting aspects is that the first three outlined stratigraphic markers fall close to one another in the different physiographic regions. This observation suggests that identifying all three markers may be the best way to correlate between the composite stratigraphies. Also, there may be a common and underlying cause for (a) the increased variability and amount of coarse fraction material delivered to these regions, (b) the basin-wide change in magnetic mineralogy within the sediments and (c) the preservation/deposition of calcareous foraminifers throughout the Arctic Ocean. The link between these observations and paleoceanographic changes and/or sea ice conditions remains unknown. However, while these markers seem to be correlatable across the central Arctic Ocean, none appear to be found in sediments deposited on the Southern Yermak Plateau (Knies et al., 2009). This may be explained by the stronger influence of inflowing Atlantic water, which maintains less intensive sea ice cover and more ventilated conditions.

\section{Conclusions}

In summary, we can conclude that non-destructive physical property records, such as magnetic susceptibility and bulk density are useful for correlating widely spread core sites within similar 
depositional environments. Based on correlations of cores from all of the major ridges and plateaus, six areas were demarcated and represent unique sedimentation regimes. The sediment transport to each area must have varied uniformly through time, at least for the latter part of the Quaternary. The proposed five composite stratigraphies may be used to further develop age models and constrain interpretations of past ice transport and current patterns. By applying available age models to the composite stratigraphies, we can deduce that the highest general sedimentation rates are found on the Yermak Plateau and the lowest on the northern Mendeleev and Alpha ridges, especially towards the Canada Basin. Although no single stratigraphic feature can be unambiguously used to link cores from different physiographic regions, an up-core shift towards larger and more frequent variations in the coarse fraction content, the appearance of calcareous foraminifera and a change in the magnetic mineralogy (inferred from paleomagnetic inclination records) all point to a significant shift in paleoceanographic conditions occurring around the MIS 6/7 boundary.

\section{Acknowledgements}

The authors would like to thank the Swedish Research Secretariat, the captains and crews of the icebreakers USCGC Healy and ODEN for their support during the HOTRAX and LOMROG expeditions. This is a contribution from the Bert Bolin Centre of Climate Research at Stockholm University. Financial support was received from the Swedish Research Council (VR) and the Swedish Royal Academy of Sciences through a grant financed by the Knut and Alice Wallenberg Foundation.

\section{Appendix. Supplementary information}

Supplementary material associated with this article can be found in the online version at doi:10.1016/j.quascirev.2010.06.005.

\section{References}

Aagaard, K., Swift, J.H., Carmack, E.C., 1985. Thermohaline circulation in the Arctic Mediterranean seas. Journal of Geophysical Research 90 (C3), 4833-4846.

Adler, R.E., Polyak, L., Ortiz, J.D., Kaufman, D.S., Channell, J.E.T., Xuan, C. Grottoli, A.G., Sellén, E. Crawford, K.A., 2009. Sediment record from the western Arctic Ocean with an improved Late Quaternary age resolution: HOTRAX core HLY0503-8JPC, Mendeleev Ridge. Global and Planetary Change. doi:10.1016/ j.gloplacha.2009.03.026.

Aldahan, A.A., Ning, S., Possnert, G., Backman, J., Boström, K., 1997. ${ }^{10}$ Be records from sediment of the Arctic Ocean covering the past $350 \mathrm{ka}$. Marine Geology 144 $147-162$.

Backman, J., Fornaciari, E., Rio, D., 2009. Biochronology and paleoceanography of late Pleistocene and Holocene calcareous nannofossil abundances across the Arctic Basin. Marine Micropaleontology 72, 86-98. doi:10.1016 j.marmicro.2009.04.001.

Backman, J., Jakobsson, M., Frank, M., Sangiorgi, F., Brinkhuis, H., Stickley, C., O’Regan, M., Løvlie, R., Pälike, H., Spofforth, D., Gattacceca, J., Moran, K., King, J. Heil, C., 2008. Age model and core-seismic integration for the cenozoic ACEX sediments from the Lomonosov ridge. Paleoceanography 23, PA1S03. doi:10.1029/2007PA001476.

Backman, J., Jakobsson, M., Løvlie, R., Polyak, L., Febo, L.A., 2004. Is the central Arctic a sediment starved basin? Quaternary Science Reviews 23, 1435-1454.

Bergmann, U., 1996. Interpretation digitaler Parasound Echolotaufzeichnungen im östlichen Arktischen Ozean auf der Grundlage physikalischer Sedimenteigenschaften, Berichte zur Polarforschung, AWI, Bremerhaven, 183, 164 pp. Data extracted from Bergmann, U., 1996. Physical properties of sediment core PS2213-6. doi:10.1594/PANGAEA.50153 and Bergmann, U., 1996. Physical properties of sediment core PS2200-5. doi:10.1594/PANGAEA.50147.

Best, A.I., Gunn, D.E., 1999. Calibration of marine sediment core loggers for quantitative acoustic impedance studies. Marine Geology 160, 137-146.

Bischof, J., 2000. Ice Drift, Ocean Circulation and Climate Change. Praxis Publishing Ltd, Chichester, 215 pp.

Bischof, J., Darby, D., 1997. Mid- to Late Pleistocene ice drift in the western arctic ocean: evidence for a different circulation in the past. Science $277,74-78$.

Björk, G., Jakobsson, M., Rudels, B., Swift, J.H., Anderson, L., Darby, D.A., Backman, J., Coakley, B., Winsor, P., Polyak, L., Edwards, M., 2007. Bathymetry and deep- water exchange across the Lomonosov Ridge at $88^{\circ}-89^{\circ} \mathrm{N}$. Deep Sea Research Part I - Oceanographic Research Papers 54, 1197-1208.

Brozena, J.M., Childers, V.A., Lawver, L.A., Gahagan, L.M., Forsberg, R., Faleide, J.I. Eldholm, O., 2003. New aerogeophysical study of the Eurasia Basin and Lomonosov Ridge: implications for basin development. Geology 31 (9), 825-828.

Channell, J.E.T., Xuan, C., 2009. Self-reversal and apparent magnetic excursions in Arctic sediments. Earth and Planetary Science Letters 284, 124-131.

Clark, D.L., Chern, L.A., Hogler, J.A., Mennicke, C.M., Atkins, E.D., 1990. Late Neogene climate evolution of the Central Arctic Ocean. Marine Geology 93, 69-94.

Clark, D.L., Whitman, R.R., Morgan, K.A., Mackay, S.D., 1980. Stratigraphy and glacialmarine sediments of the Amerasian Basin, central Arctic Ocean. Geological Society of America Special Paper 181, 1-57.

Comiso, J.C., Parkinson, C.L., Gersten, R., Stock, L., 2008. Accelerated decline in the Arctic sea ice cover. Geophysical Research Letters 35, L01703. doi:10.1029/ 2007GL031972).

Cronin, T.M., Smith, S.A., Eynaud, F., O’Regan, M., King, J., 2008. Quaternary paleoceanography of the central arctic based on integrated ocean drilling program arctic coring expedition 302 foraminiferal assemblages. Paleoceanography 23 (1).

Darby, D., 1971. Carbonate Cycles and Clay Mineralogy of Arctic Ocean Sediment Cores. University of Wisconsin-Madison Arctic Ocean Sediment Studies, Technical report 8: $43 \mathrm{pp}$.

Darby, D., Jakobsson, M., Polyak, L., HOTRAXscienceparty, 2005. Icebreaker expedition collects key Arctic seafloor and ice data. EOS Transactions, American Geophysical Union 86 (52), 549-552.

Darby, D.A., 1989. Sediment composition and sedimentary processes in the Arctic Ocean. In: Herman, Y. (Ed.), The Arctic Seas. Van Nostrand Reinhold Company, New York, pp. 657-720.

Darby, D.A., 2003. Sources of sediment found in sea ice from the western Arctic Ocean, new insights into processes of entrainment and drift patterns. Journal of Geophysical Research 108 (C8), 3257. doi:10.1029/2002JC001350.

Darby, D.A., 2008. Arctic perennial ice cover over the last 14 million years. Paleoceanography, 23, PA1S07, doi:10.1029/2007PA001479.

Dowdeswell, J.A., Jakobsson, M., Hogan, K.A., O’Regan, M., Backman, J., Evans, J., Marcussen, C., Noormets, R., Ó Cofaigh, C. High-resolution geophysical observations from the Yermak Plateau and northern Svalbard margin: implications for ice grounding and deep-keeled icebergs. Quaternary Science Reviews, this issue.

Fahl, K., Nöthig, E.M., 2007. Lithogenic and biogenic particle fluxes on the Lomonosov Ridge (central Arctic Ocean) and their relevance for sediment accumulation: Vertical vs. lateral transport. Deep Sea Research Part I - Oceanographic Research Papers 54 (8), 1256-1272.

1992 Fütterer, D., 1992. Arctic '91: The Expedition ARK-VIII/3 of RV "Polarstern" in 1991. Berichte zur Polarforschung, 107: 271

Geotek, 2004. Multi-sensor Core Logger. ver. 11-08.

Haley, B.A. Frank, M. Spielhagen, R.F, Eisenhauer, A, 2008. Influence of brine formation on Arctic Ocean circulation over the past 15 million years. Nature Geoscience 1, 68-72.

Hall, J.K., 1990. Chukchi borderland. In: Grantz, A., Johnson, G.L., Sweeney, J.F. (Eds.), The Arctic Ocean Region. Geology of North America. Geological Society of America, Boulder, CO, pp. 337-350.

Hanslik, D., Jakobsson, M., Backman, J., Björck, S., Sellén, E., O'Regan, M., Fornaciari, E., Skog, G. Pleistocene Arctic Ocean sea ice and deep water isolation times. Quaternary Science Reviews, this issue.

Hounslow, M.W., Maher, B.A., 1999. Source of the climate signal recorded by magnetic susceptibility variations in Indian Ocean sediments. Journal of Geophysical Research 104 (B3), 5047-5061.

Jackson, H.R., Oakey, G.N., 1990. Sedimentary thickness map of the Arctic Ocean. In: Grantz, A. (Ed.), The Geology of North America. The Arctic Ocean Region, vol. L. The Geolological Society of America, Boulder.

Jakobsson, M., Backman, J., Murray, A., Løvlie, R., 2003a. Optically stimulated luminescence dating supports central Arctic Ocean cm-scale sedimentation rates. Geochemistry, Geophysics, Geosystems 4, 1-11.

Jakobsson, M., Gardner, J.V., Vogt, P.R., Mayer, L.A., Armstrong, A., Backman, J. Brennan, R., Calder, B., Hall, J.K., Kraft, B., 2005. Multibeam bathymetric and sediment profiler evidence for ice grounding on the Chukchi Borderland, Arctic Ocean. Quaternary Research 63, 150-160.

Jakobsson, M., Grantz, A., Kristoffersen, Y., Macnab, R., 2003b. Physiographic province of the Arctic Ocean. Geological Society of America Bulletin 115 (12), 1443-1455.

Jakobsson, M., Løvlie, R., Al-Hanbali, H., Arnold, E., Backman, J., Mörth, M., 2000 Manganese and color cycles in Arctic Ocean sediments constrain Pleistocene chronology. Geology 28, 23-26.

Jakobsson, M., Løvlie, R., Arnold, E.M., Backman, J., Polyak, L., Knudsen, J.-O. Musatov, E., 2001. Pleistocene stratigraphy and paleoenvironmental variation from Lomonosov Ridge sediments, central Arctic Ocean. Global and Planetary Change 31, 1-22.

Jakobsson, M., Macnab, R., Mayer, M., Anderson, R., Edwards, M., Hatzky, J., Schenke, H.W., Johnson, P., 2008a. An improved bathymetric portrayal of the Arctic Ocean: Implications for ocean modeling and geological, geophysical and oceanographic analyses. Geophysical Research Letters 35, LO7602. doi:10.1029/2008GL033520.

Jakobsson, M., Marcussen, C., LOMROG Scientificparty, 2008b. Lomonosov Ridge off Greenland 2007 (LOMROG) - Cruise Report, Special publication Geological Survey of Denmark and Greenland, Copenhagen, Denmark.

Jakobsson, M., Nilsson, J., O'Regan, M.A., Backman, J., Löwemark, L., Dowdeswell, J.A., Colleoni, F., Marcussen, C., Anderson, L., Björk, G., Darby, D., Eriksson, B. Hanslik, D., Hell, B., Mayer, L., Polyak, L., Sellén, E., Wallin, Å. An Arctic Ocean ice 
shelf during MIS 6 constrained by new geophysical and geological data. Quaternary Science Reviews, this issue.

Jakobsson, M., Polyak, L., Edwards, M., Kleman, J., Coakley, B., 2008c. Glacial geomorphology of the Central Arctic Ocean: the Chukchi Borderland and the Lomonosov Ridge. Earth Surface Processes and Landforms 33, 526-545.

Jenkyns, H.C., Forster, A., Schouten, S., Sinninghe Damsté, J.S., 2004. High temperatures in the Late Cretaceous Arctic Ocean. Nature 432, 888-892.

Jokat, W., 1999a. ARCTIC '98: the expedition ARK-XIV/1a of RV “Polarstern" in 1998. Berichte zur Polarforschung, AWI, Bremerhaven, 308, 159 pp. Data extracted from Stein, R., Usbeck, R., Polozek, K., 1999. Continuous whole-core logging of wet bulk density, P-wave velocity and magnetic susceptibility.

Jokat, W., 1999b. Expedition gives fresh view of Central Arctic geology. EOS Transactions, American Geophysical Union 80 (465), 472-473.

Jokat, W., 2000. The Expedition ARKTIS-XV/2 of Polarstern in 1999. Alfred Wegener Institute for Polar and Marine Research, Bremerhaven.

Jokat, W., 2003. Seismic investigations along the western sector of Alpha Ridge, Central Arctic Ocean. Geophysical Journal International 152, 185-201.

Jokat, W., 2005. The sedimentary structure of the Lomonosov Ridge between $88^{\circ} \mathrm{N}$ and $80^{\circ} \mathrm{N}$. Geophysical Journal International $163(2), 698-726$

Kaufman, D.S., Polyak, L., Adler, R., Channell, J.E.T., Xuan, C., 2008. Dating late Quaternary planktonic foraminifer Neogloboquadrina pachyderma from the Arctic Ocean by using amino acid racemization. Paleoceanography 23, PA3224. doi:10.1029/2008PA001618)

Knies, J., 1994. Spätquartäre Sedimentation am Kontinentalhang nordwestlich Spitzbergens. Der letzte Glazial/Interglazial-Zyklus. Diploma thesis, Fachbereich Geowissenschaften und Geographie der Justus-Liebig-Universität Giessen \& AWI, Bremerhaven, 95 pp., hdl:10013/epic.33262.d001. Data extracted from Knies, J., 1994. Sedimentology and geochemistry of core PS2123-2. doi:10.1594/ PANGAEA.227626.

Knies, J., Matthiessen, J., Vogt, C., Laberg, J.S., Hjelstuen, B.O., Smelror, M., Larsen, E., Andreassen, K. Eidvin, T., Vorren, T.O., 2009. The Plio-Pleistocene glaciation of the Barents Sea-Svalbard region: a new model based on revised chronostratigraphy. Quaternary Science Reviews, 1-18. doi:10.1016/ j.quascirev.2008.12.002

Kristoffersen, Y., Coakley, B., Jokat, W., Edwards, M., Brekke, H., Gjengedal, J., 2004. Seabed erosion on the Lomonosov Ridge, central Arctic Ocean: a tale of deep draft icebergs in the Eurasia Basin and the influence of Atlantic water inflow on iceberg motion? Paleoceanography 19, PA3006. doi:10.1029/2003PA000985).

Kristoffersen, Y., Mikkelsen, Y., 2006. On sediment deposition and nature of the plate boundary at the junction between the submarine Lomonosov Ridge, Arctic Ocean and the continental margin of Arctic Canada/North Greenland. Marine Geology 225 (1-4), 265-278.

Krylov, A.A., Andreeva, I.A., Vogt, C., Backman, J., Krupskaya, V.V., Grikurov, G.E., Moran, K., Shoji, H., 2008. A shift in heavy and clay mineral provenance indicates a middle Miocene onset of a perennial sea ice cover in the Arctic Ocean. Paleoceanography $23(1)$

Lebedeva-Ivanova, N.N., Zamansky, Y.Y., Langinen, A.E., Sorokin, M.Y., 2006. Seismic profiling across the Mendeleev Ridge at $82^{\circ} \mathrm{N}$ : evidence of continental crust. Geophysical Journal International 165 (2), 527-544.

Lisiecki, L.E., Raymo, M.E., 2005. A Pliocene-Pleistocene stack of 57 globally distributed benthic $\delta^{18} \mathrm{O}$ records. Paleoceanography 20, PA1003. doi:10.1029/ 2004PA001071). 17

Menard, H.W., Smith, S., 1966. Hypsometry of ocean basin provinces. Journal of Geophysical Research 71 (18), 4305-4325.

Minicucci, D.A., Clark, D.L., 1983. A Late Cenozoic stratigraphy for glacial-marine sediments of the eastern Alpha Cordillera, central Arctic Ocean. In: Molnia, B.F. (Ed.), Glacial-marine Sedimentation. Plenum Press, New York, pp. 331-365.

Möller, P., Lubinski, D.J., Ingólfsson, Ó., Forman, S.L., Seidenkrantz, M.-S., Bolshiyanov, D.Y., Lokrantz, H., Antonov, O., Pavlov, M., Ljung, K., Zeeberg, J., Andreev, A., 2006. Severnaya Zemlya, Arctic Russia: a nucleation area for Kara Sea ice sheets during the Middle to late Quaternary. Quaternary Science Reviews 25, 2894-2936.

Moran, K., Altmann, V., O’Regan, M., Ashmanka, C., 2007. Acoustic compressional wave velocity as a predictor of glaciomarine sediment grain size. ASTM Geotechni, 7-273.

Moran, K., Backman, J., Brinkhuis, H., Clemens, S.C., Cronin, T., Dickens, G.R., Eynaud, F., Gattacceca, J., Jakobsson, M., Jordan, R.W., Kaminski, M., King, J., Koç, N., Krylov, A., Martinez, N., Matthiessen, J., McInroy, D., Moore, T.C., Onadera, J., O'Regan, M. Pälike, H., Rea, B., Rio, D., Sakamoto, T. Smith, D.C. Stein, R., St John, K., Suto, I., Suzuki, N., Takahashi, K., Watanabe, M., Yamamoto, M., Farrell, J., Frank, M., Kubik, P., Jokat, W., Kristoffersen, Y., 2006. The Cenozoic paleoenvironment of the Arctic Ocean. Nature 441, 601-605.

Mudie, P.J., Blasco, S.M., 1985. Lithostratigraphy of the CESAR cores. In: Jackson, H.R. Mudie, P.J., Blasco, S.M. (Eds.), Initial Geological Report on CESAR - the Canadian Expedition to Study the Alpha Ridge, Arcitc Ocean. Geological Survey of Canada, Ottawa, pp. 59-99.

Myhre, A.M., Thiede, J., 1995. North Atlantic-Arctic gateways. In: Myhre, A.M., Thiede, J., Firth, J.V. (Eds.), Proceedings of the Ocean Drilling Program, Initial Reports, vol. 151, pp. 5-26.

Nowaczyk, N. R., Frederichs, T., 2009. Magentic susceptibility raw data of 78 sediment cores from the Arctic Ocean sampled during POLARSTERN cruise ARK-VIII/ 3. GeoForschungsZentrum Potsdam, doi:10.1594/PANGAEA.712144.

Niessen, F., Magens, D., Gebhardt, A.C., 2007. Physical properties of the AND-1B Core, ANDRILL McMurdo ice shelf project, Antarctica. Terra Antarctica 14 (3), 155-166.
Nørgaard-Pedersen, N., Mikkelsen, N., Kristoffersen, Y., 2007. Arctic Ocean record of last two glacial-interglacial cycles off North Greenland/Ellesmere Island implications for glacial history. Marine Geology 244 (1-4), 93-108.

O’Regan, M., King, J., Backman, J., Jakobsson, M., Pälike, H., Moran, K., Heil, C., Sakamoto, T., Cronin, T., Jordan, R., 2008. Constraints on the Pleistocene chronology of sediments from the Lomonosov Ridge. Paleoceanography 23, PA1S19. doi:10.1029/2007PA001551.

O’Regan, M., St. John, K., Moran, K., Backman, J., King, J., Haley, B.A., Jakobsson, M., Frank, M., Röhl, U., 2009. Plio-Pleistocene trends in ice rafted debris on the Lomonosov Ridge. Quaternary International. doi:10.1016/j.quaint.2009.08.010.

Peterson, B.J., Holmes, R.M., McClelland, J.W., Vörösmarty, C.J., Lammers, R.B., Shiklomanov, A.I., Shiklomanov, I.A., Rhamstorf, S., 2002. Increasing river discharge to the Arctic Ocean. Science 298 (5601), 2171-2173.

Pfirman, S.L., Colony, R., Nurnberg, D., Eicken, H., Rigor, I., 1997. Reconstructing the origin and trajectory of drifting Arctic sea ice. Journal of Geophysical Research Oceans 102 (C6), 12575-12586.

Phillips, L.R., Grantz, A., 2001. Regional variations in provenance and abundance of ice-rafted clasts in Arctic Ocean sediments: implications for the configuration of Late Quaternary oceanic and atmospheric circulation in the arctic. Marine Geology 172, 91-115.

Polyak, L., Bischof, J., Ortiz, J.D., Darby, D.A., Channell, J.E.T., Xuan, C., Kaufman, D.S., Løvlie, R., Schneider, D.A., Eberl, D.D., Adler, R.E. Council, E.A., 2009. Late Quaternary stratigraphy and sedimentation patterns in the western Arctic Ocean. Global and Planetary Change. doi:10.1016/j.gloplacha.2009.03.014.

Polyak, L., Curry, W.B., Darby, D.A., Bischof, J., Cronin, T.M., 2004. Contrasting glacial/ interglacial regimes in the western Arctic Ocean as exemplified by a sedimentary record from the Mendeelev Ridge. Palaeogeography, Palaeoclimatology, Palaeoecology 203, 73-93.

Polyak, L., Darby, D., Bischof, J.F., Jakobsson, M., 2007. Stratigraphic constraints on late Pleistocene glacial erosion and deglaciation of the Chukchi margin, Arctic Ocean. Quaternary Research 67, 234-245.

Polyak, L., Edwards, M.H., Coakley, B.J., Jakobsson, M., 2001. Ice shelves in the Pleistocene Arctic Ocean inferred from glaciogenic deep-sea bedforms. Nature 410, 453-457.

Poore, R.Z., Ishman, S.E., Phillips, L., McNeil, D., 1994. Quaternary stratigraphy and paleoceanography of the Canada Basin, western Arctic Ocean. US Geological Survey Bulletin 2080, 1-32.

Rabineau, M., Berne, S., Olivet, J.L., Aslanian, D., Guillocheau, F., Joseph, P., 2007. Paleo sea levels reconsidered from direct observation of paleoshoreline position during Glacial Maxima (for the last 500,000 years). Earth and Planetary Science Letters 254 (3-4), 446-447.

Rack, F.R., Bloemendal, J., Wolf-Welling, T.C.W., O'Connell, S., Cremer, M., Winkler, A., Thiede, J., Black, K., Hood, J., 1996. Development of physical properties relationships, interhole composite depth profiles, and sedimentology ground truthing of multi-sensor core measurements: A synthesis of results. In: Thiede, J., Myhre, A.M., Firth, J.V., Johnson, G.L., Ruddiman, W.F. (Eds.), Proceedings of the Ocean Drilling Program, Scientific Results, pp. 595-626.

Rudels, B., 1995. The thermohaline circulation of the Artic Ocean and the Greenland Sea. Philosophical Transactions: Physical Sciences and Engineering 352, 287-299.

Rudels, B., Anderson, L., Eriksson, P., Fahrbach, E., Jakobsson, M., Jones, E.P., Melling, H., Prinsenberg, S., Schauer, U. and Yao, T., in press. ACSYS chapter 4: Observations in the ocean. In: Lemke, P. (Ed.), ARCTIC climate change - the ACSYS decade and beyond. Springer Verlag, Berlin.

Schneider, D.A., 1996. Paleomagnetic constraints on sedimentation rates in eastern Arctic Ocean. Quaternary Research 46, 62-71.

Sellén, E., Jakobsson, M., Backman, J., 2008. Sedimentary regimes in Arctic's Amerasian and Eurasian Basins: clues to differences in sedimentation rates. Global and Planetary Change 61 (3-4), 275-284.

Sellén, E., Jakobsson, M., Frank, M., Kubik, P.W., 2009. Pleistocene variations of beryllium isotopes in central Arctic Ocean sediment cores. Global and Planetary Change 68, 38-47. doi:10.1016/j.gloplacha.2009.03.024.

Spielhagen, R.F., Baumann, K.H., Erlenkeuser, H., Nowaczyk, N.R., NørgaardPedersen, N., Vogt, C., Weiel, D., 2004. Arctic Ocean deep-sea record of northern Eurasian ice sheet history. Quaternary Science Reviews 23 (11-13), 1455-1483. Data extracted from Spielhagen, R.F., 2004. Sedimentology and age control parameter of core 2200-5. doi:10.1594/PANGAEA.206408.

Stein, R., Usbeck, R., Polozek, K., 2004. Physical properties of sediment core PS51/ 034-4. doi:10.1594/PANGAEA.205429.

Svendsen, J.I., Alexanderson, H., Astakhov, V.I., Demidov, I., Dowdeswell, J.A., Funder, S., Gataullin, V., Henriksen, M., Hjort, C., Houmark-Nielsen, M., Hubberten, H.W., Ingólfsson, Ó., Jakobsson, M., Kjær, K.H., Larsen, E., Lokrantz, H., Lunkka, J.P., Lyså, A., Mangerud, J., Matiouchkov, A., Murray, A., Möller, P., Niessen, F., Nikolskaya, O., Polyak, L., Saarnisto, M., Siegert, C., Siegert, M.J., Spielhagen, R.F., Stein, R., 2004. Late Quaternary ice sheet history of northern Eurasia. Quaternary Science Reviews 23 (11-13), 1229-1271.

Verosub, K.L., Roberts, A.P., 1995. Environmental magnetism: past, present, and future. Journal of Geophysical Research 100 (B2), 2175-2192.

Vogt, C., 2009. Data report: semiquantitative determination of detrital input to ACEX sites based on bulk sample X-ray diffraction data. In: Backman, J., Moran, K., McInroy, D.B., Mayer, L.A., A.T.E.Scientists (Eds.), Proceedings of the Integrated Ocean Drilling Program, 302. Integrated Ocean Drilling Program Management International, Inc., Edinburgh. doi:10.2204/ iodp.proc.302.203.2009. 
Vogt, C., 1997. Zeitliche und räumliche Verteilung von Mineralvergesellschaftungen in spätquartären Sedimenten des Arktische Ozeans und ihre Nützlichkeit als Klimaindikatoren während der Glazial/InterglazialWechsel, vol. 251. Berichte zur Polarforschung, AWI, Bremerhaven. 309pp. Data extracted from Vogt, C., 2004. Mineralogy of sediment core PS2200-5. doi:10.1594/PANGAEA.138272.

Vogt, P.R., Crane, K., Sundvor, E. 1994. Deep Pleistocene iceberg plowmarks on the Yermak Plateau: sidescan and $3.5 \mathrm{kHz}$ evidence for thick calving ice fronts and a possible marine ice sheet in the Arctic Ocean. Geology 22 (5), 403-406.

Weber, M.E., Niessen, F., Kuhn, G., Wiedicke, M., 1997. Calibration and application of marine sedimentary physical properties using a multi-sensor core logger. Marine Geology 136 (3-4), 151-172.

Woodgate, R.A., Aagaard, K., 2005. Revising the Bering Strait freshwater flux into the Arctic Ocean. Geophysical Research Letters 32, L02602. doi:10.1029/ 2004 GL021747. 